\title{
PHYSIOLOGICAL STUDIES ON SUGAR PEA: EFFECT OF PLANT DENSITY AND SOME NATURAL SUBSTANCES AS FOLIAR APPLICATIONS ON GROWTH, POD YIELD AND QUALITY. \\ El-Sayed, Hala A. ${ }^{1}$; M. M. B. Shokr ${ }^{2}$ and M. A. A. EL-Sherbini ${ }^{2}$ \\ 1. Veg. and Flori. Dept., Fac. of Agric., Mans. Univ., Egypt. \\ 2. Veg. Res. Dept., Hort. Res. Inst., Agric. Res. Center, Giza, Egypt.
}

\begin{abstract}
Two field experiments were conducted at Private Farm in EL-Salheya, SharKia Governorate, Egypt during winter seasons of 2012/2013 and 2013/2014 to study the effect of plant density and some foliar applications, i.e., moringa leaf extract (MLE), chitosan at $150 \mathrm{ppm}$ and silicon at $200 \mathrm{ppm}$ on vegetative growth, pod yield and quality of snow pea cultivars, i.e. "Compados and Snow Wind" and sugar snap pea cultivar "Sugar Snap".

The results showed that Compados cultivar had more leaves and branches, longest plant height, heaviest fresh and dry weight, largest leaf area, and gave the highest pod length and pod yield (ton/fed.) compared with other cultivars in the two seasons. Whereas, the least one was Sugar Snap cultivar in both seasons. Moreover, Sugar Snap cultivar was the highest in pod thickness, total soluble solids (TSS) and carbohydrates (\%) and the lowest in titrable acidity (\%) in both seasons. While, Snow Wind was the superior in vitamin $C(\mathrm{mg} / 100 \mathrm{~g} \mathrm{fw})$ in both seasons. Meanwhile, plant density $(20 \mathrm{~cm}$ apart) gave the highest plants and total pod yield/fed. compare with other densities $(40$ and $60 \mathrm{~cm})$ at the two seasons whereas, $(60 \mathrm{~cm}$ apart) gave the highest values in all studied parameters except plant height and total pod yield/fed followed by $(40 \mathrm{~cm}$ apart plants) in both seasons. All foliar applications significantly increased all the studied parameters compared to the control treatment. The superior application was moringa leaf extract (MLE) followed by chitosan and silicon in both seasons, respectively.

From the obtained results it could be concluded that Compados cultivar was the highest pod yield/plant, and total yield/fed. when cultivated on $20 \mathrm{~cm}$ apart, meanwhile Sugar Snap cultivar gave the best pod quality when cultivated on $60 \mathrm{~cm}$ apart and sprayed with moringa leaf extract three times, i.e., 15 days after planting then repeated each 15 days interval, respectively.
\end{abstract}

Keywords: Sugar pea, moringa leaf extract, chitosan, silicon, growth, pod yield, quality.

\section{INTRODUCTION}

Sugar pea is one of the important newly introduced vegetable crops in Egypt for exporting. Sugar peas contain two types, i.e. the snow peas and the sugar snap peas which they are known as edible podded peas because they don't have the same cross fiber in the wall of the pod as the common garden pea and pods can be eaten whole. The snow pea (Pisum sativum var. macrocarpon) is known by this name in Australia and the USA, but in England and France, it is called "mange-tout" which means "eat-all". The snow pea is a distinct botanical cultivar or subspecies of pisum sativum. The pod of snow pea is slab sided and is eaten before the string develops and 
the peas start to swell. While, the sugar snap pea or snap pea (Pisum sativum var. saccharatum) is the progeny of a cross between a snow pea and unusual pea that was tightly podded with thick walls. The sugar snap pea is a pea which snaps like a green bean, the pod have thick walls, and are sweet. Unlike the snow pea, the sugar snap pea is picked more mature and is fully rounded (Beckingham, 2001 and Burt, 2008). Pods of sugar pea contain a great amount of protein, carbohydrates, vitamins, minerals and other nutrients, so that sugar pea considered as one of the most important sources in human food nutrition. It can be eaten raw, lightly boiled, steamed or used in stri-frys.

Plant population density is a major determinant of crop yield. In fact, the yield of plant is the result of the competition within and outside of the plant on the environmental factors and the maximum yield will be obtained when, this competition has decreased and the plant has the maximum using of these environmental factors. Increasing the excessive density, prevent the light penetrating into the canopy and increase competition. Therefore, identifying the suitable planting density is the first and the most essential strategies considered for achieving high yield (Rasaei et al., 2012). For this reason, managing this new crop is uncertain and knowledge about its agronomic response is required. Clarification of the effect of seeding density on the yield and quality is especially needed. There is no published information on the effect of these factors on the snap pea, but similar studies have been conducted on peas (Azpilicueta et al., 2012). In addition, it became important to work on increasing the production and the quality of this crop especially with the increased demand for exporting sugar peas.

One of these strategies for increasing the production and the quality of sugar peas using natural growth stimulating compounds safety to the environment, inexpensive and harmless to humans, i.e., moringa leaf extract and chitosan applications. Moringa (Moringa oleifera) is an important plant of Morigaceae family having tremendous allelopathic potential. There are about 13 species of genus Moringa reported in total and among them $\mathrm{M}$. oleifera is the most known and widely cultivated species throughout the world (Fuglie, 1999). Moringa is known as a miracle plant due to its multiple uses. Being rich in amino acids, ascorbate, zeatin, minerals and many other compounds, moringa has several applications in agriculture and medical sciences. Secondary metabolites isolated from this plant promote the plant growth and defense mechanisms against abiotic stresses. Moringa extracts accelerate the growth of plants, strengthen plants, and improve resistance against pests and diseases (Hussain et al., 2013). Moringa leaf extract (MLE) being a rich source of amino acids, essential macro- and microplant minerals, vitamins, natural antioxidants and plant growth regulators such as zeatin (cytokinins) and gibberellins; it can be effectively exploited as plant growth enhancer (Makkar and Becker, 1996; Mahmood et al., 2010 and Basra et al., 2011). Furthermore, foliar spray of leaf extracts of moringa accelerate the growth of plants, improves resistance to pests and diseases, and enhances the yield by $20-35 \%$ in different crops (Fuglie, 2000).

Chitosan is a natural, low toxic and inexpensive compound that is biodegradable and environmentally friendly with various applications in 
agriculture. Structurally, chitosan is a straight-chain copolymer composed of D-glucosamine and $\mathrm{N}$-acetyl-D-glucosamine being obtained by the partial deacetylation of chitin. It is the most abundant basic biopolymer and it's structurally similar to cellulose, which is composed of only one monomer of glucose (De Alvarenga, 2011). Chitosan is derived from chitin, a polysaccharide found in the exoskeleton of shellfish such as shrimp, lobster, and or crabs and cell walls of fungi (Wojdyla, 2001). Recently, chitosan has been reported to act as a plant growth regulator and considered to elicit the induction of plant defense mechanisms in many plant (Ben-Shalom et al., 2003 and Photchanachai et al., 2006). Both chitin and chitosan have demonstrated antiviral, antibacterial, and antifungal properites, and have been explored for many agricultural uses. They have been utilized to control disease or reduce their spread, to chelate nutrient and minerals, preventing pathogens from accessing them, or to enhance plant innate defenses (El hadrami et al., 2010). Moreover, chitosan has been shown to stimulate plant growth (Kim, 2005 and Mondal et al., 2012), to possess antioxidant activity (Xie et al., 2001 and Chen et al., 2009), act as anti-transpirant compound that has proved to be effective in many crops (Khan et al., 2002 and Karimi et al., 2012) and to improve storability of postharvest fruits and vegetables (El Ghaouth et al., 1991).

Among the tools for increasing productivity and quality of sugar pea using silicon ( $\mathrm{Si}$ ) application. Although silicon is the second most abundant element both on the surface of the Earth's crust and in soils, it has not yet been listed among the essential elements for higher plants. Like salt in food, which itself is not a nutrient or food item but adds to the taste and palatability. Similarly silicon though not essential confers rigidity and strength to plants, protects them from pests, diseases and abiotic tresses (Vasanthi et al., 2012). Among all the micronutrients assimilated by plants, silicon alone is consistently present at concentrations similar to those of the macro nutrients. It is also the only beneficial element that does not cause toxicity or serious injury to plants under excessive a mounts (Snyder et al., 2007). Its concentrations in different plants range from $0.1 \%$ (similar to $\mathrm{P}$ and $\mathrm{S}$ ) to more than $10 \%$ of whole plant dry matter (Epstein, 1999). Silicon can alleviate biotic and abiotic stresses in several crops, and it has beneficial effects on plants under nonstressed conditions (Pilon et al., 2013). The effective management of $\mathrm{Si}$ can offer several potential benefits of crop production including improved plant growth, increased yield, induced resistance to stresses and increased productivity of problem soils (Aziz et al., 2002). Moreover, silicon is an element that forms Si-enzyme complex that act as protectors and photosynthesis regulators as well as influencing other enzymatic activities (Toresano-Sanchez et al., 2012). Silicon was found to be beneficial to barley, wheat, corn, sugarcane, cucumber, tomato, citrus and other crops (Epstein, 1994).

In the light of above discussions, present study was designed to investigate the effect of plant density and foliar applications, i.e., moringa leaf extract, chitosan and silicon on growth, pod yield and quality of some sugar pea cultivars. 


\section{MATERIALS AND METHODS}

Two field experiments were conducted at Private Farm in EL-Salheya, Sharkia Governorate, Egypt during winter seasons of 2012/2013 and $2013 / 2014$ to study the effect of plant density and some foliar applications, i.e., moringa leaf extract (MLE), chitosan at $150 \mathrm{ppm}$ and silicon at $200 \mathrm{ppm}$ on vegetative growth, pod yield and quality of snow pea cultivars, i.e. "Compados and Snow Wind" and sugar snap pea cultivar "Sugar Snap" grown under drip irrigation system of sandy soil.

The physical and chemical analysis of the experimental soil are shown in Table (1).

Table (1): The physical and chemical analysis of the experimental soil.

\begin{tabular}{|l|l|l|l|}
\hline Properties & Value & Properties & \multicolumn{1}{|l|}{ Value } \\
\hline Physical & sand & Soluble anions (meq/100g soil) \\
\hline Soil texture & 1.0085 & $\mathrm{HCO}_{3}^{-}$ & 0.40 \\
\hline Organic matter \% & $\mathrm{CL}^{-}$ & 0.33 \\
\hline Chemical & $\mathrm{SO}_{4}^{--}$ & 0.04 \\
\hline E.C. (mmohs/cm) & 0.15 & \multicolumn{2}{l}{ Macro-elements (ppm) } \\
\hline pH & 9.53 & $\mathrm{~N}$ & 23.625 \\
\hline Soluble cations (meq/100g soil) & $\mathrm{P}$ & 21.00 \\
\hline $\mathrm{Ca}^{++}$ & 0.33 & $\mathrm{~K}$ & 140.00 \\
\hline $\mathrm{Mg}^{++}$ & 0.25 & $\mathrm{Micro}^{-}$elements (ppm) \\
\hline $\mathrm{Na}^{+}$ & 0.12 & $\mathrm{Fe}^{++}$ & 0.45 \\
\hline $\mathrm{K}^{+}$ & 0.07 & $\mathrm{Mn}^{++}$ & 0.62 \\
\hline \multicolumn{2}{|l|}{$\mathrm{Zn}^{++}$} & 0.45 \\
\hline & & $\mathrm{Cu}^{++}$ & 0.45 \\
\hline
\end{tabular}

Seeds were sown as two seeds per hill on one side of the irrigation lines in $20^{\text {th }}$ and $27^{\text {th }}$ of November in the first and the second seasons, respectively. The experimental layout was split-split-plot system in a randomized complete blocks design with three replicates. These experiments included 36 treatments which were the combination among 3 cultivars, 3 plant density and 4 foliar applications. The cultivars were randomly arranged in the main plots, while the plant density were randomly distributed in the sub-plots and foliar applications were randomly arranged in the sub-subplots. The sub-sub-plot area was $12.0 \mathrm{~m}^{2}$ (2 dripper lines, each $6 \mathrm{~m}$ long and $100 \mathrm{~cm}$ width). The normal agricultural practices of sugar pea production were followed according to the recommendations of Egyptian Ministry of Agriculture. The treatments were arranged as follow:

a. Sugar pea cultivars: Compados, Sugar Snap and Snow Wind.

b. Plant density: $20 \mathrm{~cm}, 40 \mathrm{~cm}$ and $60 \mathrm{~cm}$ apart.

c. Foliar applications:

1-Moringa leaf extract preparing according to Culver et al. (2012).

2-Chitosan (poly-(1.4-B-D-glucopyranosamine);2-Amino-2-deoxy-(1->4)-B-Dglucopyranan) at $150 \mathrm{ppm}$.

3-Silicon in form of (silicic acid $\left(\mathrm{Si}(\mathrm{OH})_{4}\right)$ at $200 \mathrm{ppm}$.

4-Control (sprayed with tap water).

The plants were sprayed three times, 15 days after sowing and repeated each 15 days interval. 
Data recorded:

a. Vegetative growth:

At 45 days after sowing five plants were randomly taken from each plot for determining the following data:

Plant height $(\mathrm{cm})$, number of branches/plant, number of leaves/plant, leaf area ( $\mathrm{cm}^{2} /$ plant), fresh weight (gm/plant) and dry weight ( $\left.\mathrm{gm} / \mathrm{plant}\right)$.

b. Pod yield and its components:

Green pods of each plot were harvested at the proper maturing stage, counted and weighted in each harvest and the following parameters were collected:

Number of pods/plant, average weight of pod (gm), pod yield/plant (gm) and total pod yield (ton/fed.).

c. Pod quality:

Pod length $(\mathrm{cm})$, pod diameter $(\mathrm{mm})$, pod thickness $(\mathrm{mm})$, total soluble solids (TSS) was determined by Carl Zeiss refractometer, vitamin C (mg/100gfw) was determined in juice using 2,6-dichlorophenolindophenol dye (A.O.A.C., 1990), titrable acidity (\%) was determined by the titration method with 0.1 sodium hydroxide using phenolphthalein indicator (A.O.A.C., 1990 ) and carbohydrates (\%) was determined colorimetrically in dry matter of pods following the method described by Dubois et al. (1956).

All collected data on plot basis were subjected to the statistical analysis according to the method mentioned by Snedecor and Cochran (1968). The data of treatment means were compared using least significant difference (LSD) method as mentioned by Gomez and Gomez (1984).

\section{Vegetative growth characters: \\ Effect of cultivars:}

RESULTS AND DISCUSSION

Data presented in Table (2) showed that Compados cultivar had highest values than other cultivars in all vegetable growth characters, i.e., plant height, number of leaves and branches/plant, Leaf area and fresh and dry weight followed by Snow Wind cultivar, whereas the least one was Sugar Snap cultivar in both seasons.

Similar results were obtained by Tewfik (2014) who evaluated some sugar pea cultivars and found that Compados cultivar was the best cultivar in all vegetative growth parameters compared with the other studied cultivars. Also, El-Desuki (2006) reported that Snow Wind cultivar gave the highest vegetative growth values compared with Sugar Pearl and Sugar Gem cultivars. The differences among cultivars may due to the genetical variations.

\section{Effect of plant density:}

Data in Table (2) indicated that plant density $(20 \mathrm{~cm}$ apart $)$ gave the highest plants compare with other densities $(40$ and $60 \mathrm{~cm})$ at the two seasons. Whereas, the plant density $(60 \mathrm{~cm}$ apart) gave the highest values in number of branches and leaves/plant and leaf area $\left(\mathrm{cm}^{2}\right) /$ plant and the heaviest fresh and dry weight of plant at the two seasons. The differences among plant densities were significantly in all studied characters in the two seasons. Theses results were agreed with those of Rasaei et al. (2012); 
Sajid et al. (2012) and Yucel (2013) on pea and Bakry et al. (2011) on faba bean, they reported that plant height was increased by increasing plant population. Moreover, Shaukat et al. (2012) on pea indicated that row spacing $30 \mathrm{~cm}$ gave maximum plant height $(93.8 \mathrm{~cm})$, while $50 \mathrm{~cm}$ and 60 $\mathrm{cm}$ row spacing gave minimum plant height $(84.6$ and $83.3 \mathrm{~cm})$ and more number of branches plant ${ }^{-1}$ (2.76 and 2.62), compare to $30 \mathrm{~cm}$ (1.16), respectively. The increase in number of branches per plant in lower population density may be due to more space availability to plants to spread rather to grow straight. This was the main reason that the plant height in lower population density was less and hence produces more branches, on the other hand, plant height was more in the higher plant population and gave less number of branches per plant and that due to the competition among plants for soil moisture, nutrient, light and carbon dioxide.

\section{Effect of foliar applications:}

Data presented in Table (2) showed that all foliar applications significantly increased all studied characters, i.e., plant height, number of branches and leaves/plant, leaf area $\mathrm{cm}^{2} /$ plant and fresh and dry weight/plant compared with the control. The best application in all studied characters was moringa leaf extract followed by chitosan except, the fresh weight in the second season, in which the silicon application followed moringa leaf extract. These results are in harmony with those reported by Culver et al. (2012); Yasmeen et al. (2012) and Muhamman et al. (2013) on tomato all for moringa extract; El Nagar et al. (2012) on pea; El-Tanahy et al. (2012) on cowpea; Mondal et al. (2012) on okra; Mondal et al. (2013) on mungbean all for chitosan and Mali and Aery (2009) on cowpea; Abou-Baker et al. (2011) on bean and Pilon et al. (2013) on potato all for silicon.

The favorable effect of moringa leaf extract on vegetative growth might be due to its role as a plant growth stimulator. It contains zeatin, a cytokinin that plays a role in delaying leaf senescence, in addition to other growthenhancing-compounds such as ascorbate, phenolics and minerals (Yasmeen et al., 2012). Also, Hussain et al. (2013) reported that moringa extracts accelerate the growth of plants, strengthen plants and improve resistance against pests and diseases.

Moreover, the effect of chitosan on growth might due to its role in increasing key enzymes activities of nitrogen metabolism (nitrate reductase, glutamine synthetase and protease) and improved the transportation of nitrogen in the functional leaves which enhanced plant growth and development (Qiang et al., 2007 and Mondal et al., 2012). Also, Chibu and Shibayama (2001) indicated that the positive effect of chitosan may resulted from the greater availability of amino compounds released from chitosan.

Meanwhile, the effect of silicon on plant growth may refer to that $\mathrm{Si}$ enhance the growth, improve protection against pathogens (Greger et al., 2011) and maintain of photosynthetic activity and that one of the reasons for the increased dry matter production (Agurie et al., 1992). In this respect Pilon et al. (2013) found that silicon application increased leaf area, specific leaf area, pigment concentration (chlorophyll a and carotenoids) and photosynthesis of potato. 
J. Plant Production, Mansoura Univ., Vol. 5 (7), July, 2014

2 


\section{Effect of interactions:}

Data in Tables ( 3 and 4 ) indicated that the effect of all interactions were insignificant in plant height in the two seasons except (cultivars $\times$ foliar applications) in the second season, number of branches, number of leaves except (cultivars $\times$ foliar applications) in the two seasons. Whereas, the effect of interactions was significant in leaf area in the two seasons, fresh weight except (cultivars $\times$ density), (density $\times$ foliar applications) and (cultivars $\times$ density $\times$ foliar applications) in the second season and dry weight except (density $\times$ foliar applications) and (cultivars $\times$ density $\times$ foliar applications) in the two seasons.

Table (3): Effect of the dual interaction between cultivar and density, cultivar and foliar applications and density and foliar applications on vegetative growth parameters of sugar pea in the two seasons of 2012/2013 and 2013/2014.

\begin{tabular}{|c|c|c|c|c|c|c|c|c|c|c|c|c|c|}
\hline \multirow{2}{*}{\multicolumn{2}{|c|}{ Treatments }} & \multicolumn{2}{|c|}{$\begin{array}{l}\text { Plant } \\
\text { height } \\
(\mathrm{cm})\end{array}$} & \multicolumn{2}{|c|}{\begin{tabular}{|c|} 
No of \\
branches/ \\
plant
\end{tabular}} & \multicolumn{2}{|c|}{$\begin{array}{l}\text { No of } \\
\text { leaves/ } \\
\text { plant }\end{array}$} & \multicolumn{2}{|c|}{$\begin{array}{c}\text { Leaf } \\
\text { area/plant } \\
\left(\mathrm{cm}^{2}\right)\end{array}$} & \multicolumn{2}{|c|}{$\begin{array}{c}\begin{array}{c}\text { Fresh } \\
\text { weight/plant } \\
(\mathrm{gm})\end{array} \\
\end{array}$} & \multicolumn{2}{|c|}{$\begin{array}{c}\text { Dry } \\
\text { weight/ } \\
\text { plant (gm) }\end{array}$} \\
\hline & & S1 & S2 & S1 & S2 & S1 & S2 & S1 & S2 & S1 & S2 & S1 & S2 \\
\hline \multicolumn{14}{|c|}{ Cvs X Density } \\
\hline \multirow{3}{*}{ Compados } & $n$ & 5 & 77.66 & 4.33 & 3.50 & 42.41 & 36.25 & 7.85 & 82.64 & 4.24 & 77.49 & 8.48 & 5.71 \\
\hline & $40 \mathrm{~cm}$ & 33 & 75.33 & 5.16 & 3.83 & 45.75 & 38.33 & 96.43 & 3789.35 & 20.04 & 182.79 & 31.07 & 30.56 \\
\hline & $60 \mathrm{~cm}$ & .50 & 74.00 & 5.16 & 4.00 & 49.33 & 41.75 & 58.53 & 905.95 & 227.57 & 187.76 & 36.33 & 32.69 \\
\hline \multirow{3}{*}{ Sugar Snap } & m & 4.00 & 55.08 & 3.66 & 2.83 & 34.75 & 32.00 & 30.74 & 1743.69 & 137.78 & 108.76 & 21.30 & 20.46 \\
\hline & 40 & 52.50 & 54.16 & 4.00 & 3.16 & 38.00 & 33.58 & 2102.32 & 2051.54 & 161.45 & 114.09 & 23.17 & 22.40 \\
\hline & & 50.08 & 52.83 & 4.25 & 3.33 & 42.00 & 34.58 & 669.02 & 2367.02 & 166.70 & 117.47 & 25.30 & 24.37 \\
\hline \multirow{3}{*}{ Snow Wind } & 7 & 7.08 & 64.66 & 3.83 & 2.83 & 37.66 & 33.83 & 484.95 & 1848.83 & 159.54 & 128.51 & 21.20 & 21.49 \\
\hline & $40 \mathrm{~cm}$ & 54.00 & 60.58 & 4.08 & 3.25 & 38.66 & 34.83 & 2843.94 & 2459.64 & 161.58 & 131.85 & 23.72 & 23.76 \\
\hline & 60 & 51.08 & 58.50 & 5.16 & 3.75 & 40.16 & 36.16 & 2137.83 & 2553.59 & 165.46 & 133.76 & 26.34 & 24.70 \\
\hline \multicolumn{2}{|c|}{ L.S.D at $5 \%$} & NS & NS & NS & NS & NS & NS & 25.679 & 41.018 & 4.989 & NS & 1.782 & 1.666 \\
\hline \multicolumn{14}{|c|}{ Cvs X Foliar applications } \\
\hline \multirow{4}{*}{ Compados } & LE & 62.55 & 33 & 5.55 & 4.66 & 54.22 & 43.44 & 448 & & 0.36 & 187.21 & 6.59 & 3.63 \\
\hline & Chito & 60.44 & 76.55 & 4.88 & 3.66 & 45.22 & 38.88 & 50 & 3753.76 & 23.84 & 181.08 & 34.33 & 30.27 \\
\hline & Silicon & 57.88 & 73.88 & 4.77 & 3.55 & 45.55 & 36.88 & 3815.72 & 589.52 & 24.57 & 186.71 & 31.71 & 29.90 \\
\hline & Cont & 51.88 & 70.88 & 4.33 & 3.22 & 38.33 & 35.88 & & 906.46 & 197.53 & 175.72 & 25.22 & 24.81 \\
\hline \multirow{4}{*}{ Sugar Snap } & MLE & 55.44 & 55.88 & 4.22 & 3.66 & 43.22 & 35.11 & 67 & 2186.78 & 168.85 & 120.95 & 27.15 & 25.38 \\
\hline & Chitosan & 53.00 & 54.44 & 4.00 & 3.22 & 38.44 & 34.22 & 2299.37 & 2131.37 & 162.38 & 118.62 & 23.30 & 23.81 \\
\hline & Silicon & 51.88 & 53.33 & 4.11 & 2.88 & 37.88 & 33.11 & 2227.36 & 2118.25 & 160.43 & 116.61 & 22.36 & 20.93 \\
\hline & Control & 48.44 & 52.44 & 3.55 & 2.66 & 33.44 & 31.11 & 06 & 94 & 59 & 97.59 & 20.21 & 19.51 \\
\hline \multirow{5}{*}{ Snow Wind } & MLE & 57.44 & 63.66 & 5.00 & 3.77 & 42.22 & 38.11 & 276 & 1.74 & 84.99 & 134.18 & 25.98 & 24.98 \\
\hline & Chitosan & 54.77 & 60.22 & 4.66 & 3.33 & 40.33 & 36.44 & 2684.53 & 2438.25 & 167.89 & 132.96 & 24.69 & 24.10 \\
\hline & Silico & 54.33 & 61.00 & 4.00 & 3.11 & 38.22 & 34.77 & & & 164.80 & 132.69 & 23.03 & 23.86 \\
\hline & Contr & 49.66 & 60.11 & 3.77 & 2.88 & 34.55 & $\overline{0.44}$ & & & 131.09 & 125.65 & 21.32 & 20.34 \\
\hline & $5 \%$ & NS & 2.493 & NS & NS & 2.642 & 1.881 & 30.447 & 26.539 & 4.979 & 3.234 & 1.576 & 1.453 \\
\hline \multicolumn{14}{|c|}{ ensity X Foliar applications } \\
\hline \multirow{4}{*}{$20 \mathrm{~cm}$} & $E$ & 33 & 0.00 & 4.55 & 3.66 & 43.77 & 36.33 & 3132.55 & 66 & 9.49 & 41 & 27.42 & 5.09 \\
\hline & Chitosan & 59.11 & 64.88 & 4.00 & 3.11 & 37.66 & 35.33 & 2608.93 & 2254.28 & 70.71 & 39.68 & 24.75 & 23.22 \\
\hline & Silicon & 57.44 & 65.33 & 3.88 & 2.88 & 39.11 & 33.44 & 2574.66 & 2216.36 & 176.53 & 142.43 & 22.15 & 21.88 \\
\hline & Contr & 38 & 0 & 3.33 & 2.55 & 32.55 & 31.00 & & & 145.36 & 126.49 & 20.34 & 20.03 \\
\hline \multirow{4}{*}{$40 \mathrm{~cm}$} & MLE & 57.22 & 0 & 4.88 & 4.00 & 45.66 & 39.00 & 28 & 3074.78 & 98.50 & 147.08 & 29.45 & 28.30 \\
\hline & Chitosan & 55.66 & 64.00 & 4.44 & 3.44 & 41.77 & 36.00 & 3210.23 & 2922.97 & 187.02 & 144.19 & 26.91 & 26.70 \\
\hline & Silicor & 54.33 & 61.77 & 4.22 & 3.22 & 40.33 & 34.77 & & & & 14 & 25.48 & 25.78 \\
\hline & & 49.88 & 6 & 4.11 & 3.00 & 35.44 & 32.55 & & & 154.70 & 135.15 & 22.10 & 21.52 \\
\hline \multirow{4}{*}{$60 \mathrm{~cm}$} & MLE & 54.88 & 64.88 & 5.33 & 4.44 & 50.22 & 41.33 & 3161.93 & 3248.40 & 202.37 & 150.85 & 32.65 & 30.60 \\
\hline & Chitosan & 53.44 & 62.33 & 5.11 & 3.66 & 44.55 & 38.22 & 3124.50 & 3146.12 & 196.37 & 148.80 & 30.87 & 28.26 \\
\hline & Silico & 52.33 & 61.11 & 4.77 & 3.44 & 42.22 & 36.55 & & 301 & 189.41 & 148.35 & 29.47 & 27.02 \\
\hline & Contr & 48.22 & 58.77 & 4.22 & 3.22 & 38.33 & 33.88 & 2594.18 & 2361.68 & 158.16 & 137.32 & 24.31 & 23.11 \\
\hline \multicolumn{2}{|c|}{ L.S.D at $5 \%$} & NS & NS & NS & NS & NS & NS & 30.447 & 26.539 & 4.979 & NS & NS & NS \\
\hline
\end{tabular}

S1: 2012/2013 season, S2: 2013/2014 season, MLE: moringa leaf extract and NS: not significant at 0.05 level of significance. 
J. Plant Production, Mansoura Univ., Vol. 5 (7), July, 2014

4 
In general, the best interaction was in plant height was (Compados $\times 20 \mathrm{~cm}$ $x$ moringa leaf extract) in the two seasons respectively. While, the lowest one was (Sugar Snap $\times 60 \mathrm{~cm} \times$ control) in the two seasons. Concerning the number of branches and leaves, leaf area and fresh and dry weight, (Compados $\times 60 \mathrm{~cm} \times$ moringa leaf extract) was the best interaction and the lowest one was (Sugar Snap $\times 20 \mathrm{~cm} \times$ control). That is true in the two seasons. Similar results were obtained by Bakry et al. (2011) on faba bean, they found that the interaction between varieties and plant density had significant effect in plant height and number of branches/plant in both seasons.

Yield and its components:

Effect of cultivars:

Data in Table (5) showed that Compados cultivar was the highest one in number of pods/plant (55.52 and 51.17), heaviest in pod yield/plant (173.25 and $169.60 \mathrm{gm}$ ) and total pod yield/fed. (4.173 and $4.095 \mathrm{ton}$ ) at the two seasons, respectively. On the other hand, Sugar Snap cultivar was the heaviest in average pod weight (4.40 and $4.88 \mathrm{gm})$, while the lowest one was Snow Wind $(3.03$ and $3.20 \mathrm{gm})$ in the both seasons, respectively. These results are harmony with those reported by El-Desuki (2006) and Tewfik (2014) on sugar pea; Bozoglu et al. (2007) and Singh and Singh (2011) on pea.

Table (5): Effect of cultivars, plant density and foliar applications on yield parameters of sugar pea in the two seasons of 2012/2013 and 2013/2014.

\begin{tabular}{|c|c|c|c|c|c|c|c|c|c|}
\hline \multicolumn{2}{|c|}{ Treatments } & \multicolumn{2}{|c|}{$\begin{array}{c}\text { No of } \\
\text { pod/plant }\end{array}$} & \multicolumn{2}{|c|}{$\begin{array}{l}\text { Average Pod } \\
\text { weight (gm) }\end{array}$} & \multicolumn{2}{|c|}{$\begin{array}{c}\text { Pod yield/plant } \\
\text { (gm) }\end{array}$} & \multicolumn{2}{|c|}{$\begin{array}{c}\text { Total pod yield } \\
\text { (ton/fed.) }\end{array}$} \\
\hline & & S1 & S2 & S1 & S2 & S1 & S2 & S1 & S2 \\
\hline \multirow{3}{*}{ Cvs. } & Compados & 55.52 & 51.17 & 3.11 & 3.31 & 173.25 & 169.60 & 4.173 & 4.095 \\
\hline & Sugar Snap & 35.00 & 30.91 & 4.40 & 4.88 & 154.33 & 151.30 & 3.658 & 3.597 \\
\hline & Snow Wind & 53.17 & 49.00 & 3.03 & 3.20 & 161.69 & 157.00 & 3.870 & 3.753 \\
\hline \multicolumn{2}{|c|}{ L.S.D at $5 \%$} & 0.381 & 0.585 & 0.064 & 0.022 & 2.567 & 1.864 & 0.056 & 0.036 \\
\hline \multirow{3}{*}{ Density } & $20 \mathrm{~cm}$ & 46.97 & 42.63 & 3.36 & 3.67 & 153.37 & 150.72 & 6.135 & 6.028 \\
\hline & $40 \mathrm{~cm}$ & 47.83 & 43.98 & 3.53 & 3.74 & 163.74 & 158.46 & 3.274 & 3.169 \\
\hline & $60 \mathrm{~cm}$ & 48.88 & 44.47 & 3.64 & 3.98 & 172.15 & 168.72 & 2.293 & 2.247 \\
\hline \multicolumn{2}{|c|}{ L.S.D at $5 \%$} & 0.420 & 0.368 & 0.047 & 0.025 & 1.920 & 0.922 & 0.057 & 0.020 \\
\hline \multirow{4}{*}{ Foliar } & MLE & 49.84 & 45.59 & 3.58 & 3.87 & 173.05 & 169.51 & 4.132 & 4.049 \\
\hline & Chitosan & 48.50 & 44.34 & 3.55 & 3.82 & 166.61 & 162.55 & 3.979 & 3.885 \\
\hline & Silicon & 47.98 & 44.01 & 3.53 & 3.80 & 163.76 & 160.40 & 3.917 & 3.841 \\
\hline & Control & 45.35 & 40.83 & 3.40 & 3.68 & 148.92 & 144.74 & 3.575 & 3.483 \\
\hline \multicolumn{2}{|c|}{ L.S.D at $5 \%$} & 0.478 & 0.372 & 0.033 & 0.029 & 1.644 & 1.265 & 0.042 & 0.036 \\
\hline
\end{tabular}

S1: 2012/2013 season, S2: $2013 / 2014$ season and MLE: moringa leaf extract.

\section{Effect of plant density:}

Data presented in Table (5) showed the effect of plant density on yield and its components. It is clear that all plant densities significantly affected all studied characters. The plant density $(60 \mathrm{~cm}$ apart) was the best in number of pods/plant, average pod weight, pod yield/plant, followed by $40 \mathrm{~cm}$ and 20 $\mathrm{cm}$ in the two seasons, respectively. Though, $20 \mathrm{~cm}$ apart gave the highest pod yield/fed. Results show that average pod weight, number of pods/plant and pod yield /plant were gradually reduced by increasing plant population density. Similar results were obtained by Munakamwe et al. (2012); Rasaei et al. (2012); Sajid et al. (2012); Shaukat et al. (2012) on pea and El Naim et 
al. (2011) on cowpea. Moreover, Azpilicueta et al. (2012) on sugar snap pea found that the effect of plant density on the number of pods $\mathrm{m}^{-2}$ was significant in the first season but was less clear in the second. The increase in the number of pods per plant in lower population density may be due to vigorous plants as in lower population density; plant grew vigorously and produced more branches which resulted in high number of pods plant ${ }^{-1}$. On the other hand, higher plant population, the plant growth was decreased which resulted in less number of pods plant ${ }^{-1}$ (Sajid et al., 2012). The total pods yield/fed. was increased in higher plant population compare to lower population density and that may be attributed to the highest number of plants per unit area.

\section{Effect of foliar applications:}

Data in Table (5) indicated that all foliar applications, i.e., moringa leaf extract, chitosan and silicon significantly affected on all studied parameters, i.e., number of pods/plant, average pod weight, pod yield/plant and total pod yield/fed. compared with the control in the two seasons. The highest number of pods/plant (49.84 and 45.59) and heaviest average pod weight (3.58 and $3.87 \mathrm{gm})$, pod yield/plant $(173.05$ and $169.51 \mathrm{gm})$ and total pod yield/fed (4.132 and 4.049 ton) were obtained when sugar pea plants treated with moringa leaf extract followed by chitosan and silicon foliar applications in both seasons, respectively. These results are in accordance with those obtained by Culver et al. (2012) they found that moringa leaf extract increased the yield of tomato by $20-150 \%$. Also, Hussain et al. (2013) reported that moringa leaf extract application enhanced the productivity of several arable crops such as soybean, sugarcane, corn, sorghum, black bean, coffee, bell pepper and onion ranging from 6.57 to $47.88 \%$. The effect of moringa leaf extract on yield might be connected with the role of plant growth regulators in improving crop growth and hence yield (Muhamman et al., 2013).

The effect of chitosan on yield may be due to its effects in stimulating physiological processes, improving vegetative growth, followed by active translocation of photoassimilates from source to sink tissues. The increases in plant biomass may be due to improving photosynthetic machinery (Khan et al., 2002).

Moreover, effects of silicon on yield are related to the deposition of the element under the leaf epidermis which results a physical mechanism of defense, reduces lodging, increases photosynthesis capacity and decreases transpiration losses (Korndörfer et al., 2004). Also, Matichenkov and Bocharnikova (2004) reported that numerous experiments were conducted with silicon in cucumber over a nine-year period and there was 6 to $16 \%$ increase in production with regard to the number of fruits and a 11 to $33 \%$ increase in relation to total production. Similar results were obtained by Toresano-Sanchez et al. (2012) on tomato.

\section{Effect of interactions:}

It is clearly in Tables (6 and 7) that all interactions insignificantly affected number of pods/plant except (cultivars $\times$ density) in the second season and (cultivars $\times$ foliar applications) in both seasons. Whereas, the effect was significantly in average pod weight, except (cultivars $\times$ foliar applications), 
(density $\times$ foliar applications) and (cultivars $\times$ density $\times$ foliar applications) in the first season, pod yield/plant except (cultivars $\times$ foliar applications) in the first season. Belong on, total pod yield/fed. responded significantly to all combinations, in both seasons. Generally, the best interaction in number of pods and total pod yield/plant was (Compados $\times 60 \mathrm{~cm} \times$ moringa leaf extract), whereas the lowest was (Sugar Snap $\times 20 \mathrm{~cm} \times$ control) in both seasons. As for average pod weight the best one was (Sugar Snap $\times 60 \mathrm{~cm}$ $\times$ moringa leaf extract) and the lowest was (Snow Wind $\times 20 \mathrm{~cm} \times$ control). The superior interaction in total pod yield/fed. was (Compados $\times 20 \mathrm{~cm} \times$ moringa leaf extract) and the less one was (Sugar Snap $\times 60 \mathrm{~cm} \times$ control) in both seasons. These results are in accordance with those obtained by Turk et al. (2011); Munakamwe et al. (2012) and Yucel (2013) on pea; Bakry et al. (2011) on faba bean and El Naim et al. (2011) on cowpea.

Table (6): Effect of the dual interaction between cultivar and density, cultivar and foliar applications and density and foliar applications on yield parameters of sugar pea in the two seasons of 2012/2013 and 2013/2014.

\begin{tabular}{|c|c|c|c|c|c|c|c|c|c|}
\hline \multirow{2}{*}{\multicolumn{2}{|c|}{ Treatments }} & \multicolumn{2}{|c|}{$\begin{array}{c}\text { No of } \\
\mathrm{pod} / \mathrm{plant}\end{array}$} & \multicolumn{2}{|c|}{$\begin{array}{l}\text { Average Pod } \\
\text { weight (gm) }\end{array}$} & \multicolumn{2}{|c|}{$\begin{array}{l}\text { Pod yield/plant } \\
\text { (gm) }\end{array}$} & \multicolumn{2}{|c|}{$\begin{array}{l}\text { Total pod yield } \\
\text { (ton/fed.) }\end{array}$} \\
\hline & & S1 & S2 & S1 & S2 & S1 & S2 & S1 & S2 \\
\hline \multicolumn{10}{|c|}{ Cvs X Density } \\
\hline \multirow{3}{*}{ Compados } & $20 \mathrm{~cm}$ & 54.64 & 50.56 & 3.04 & 3.24 & 166.33 & 164.00 & 6.653 & 6.560 \\
\hline & $40 \mathrm{~cm}$ & 55.15 & 51.16 & 3.14 & 3.31 & 173.66 & 169.56 & 3.473 & 3.391 \\
\hline & $60 \mathrm{~cm}$ & 56.77 & 51.77 & 3.16 & 3.38 & 179.75 & 175.25 & 2.394 & 2.334 \\
\hline \multirow{3}{*}{ Sugar Snap } & $20 \mathrm{~cm}$ & 34.15 & 30.38 & 4.15 & 4.63 & 141.91 & 140.91 & 5.676 & 5.636 \\
\hline & $40 \mathrm{~cm}$ & 34.77 & 31.07 & 4.39 & 4.74 & 153.07 & 147.58 & 3.061 & 2.961 \\
\hline & $60 \mathrm{~cm}$ & 36.07 & 31.29 & 4.65 & 5.27 & 168.00 & 165.41 & 2.237 & 2.203 \\
\hline \multirow{3}{*}{ Snow Wind } & $20 \mathrm{~cm}$ & 52.11 & 46.95 & 2.91 & 3.13 & 151.88 & 147.25 & 6.075 & 5.890 \\
\hline & $40 \mathrm{~cm}$ & 53.58 & 49.70 & 3.06 & 3.18 & 164.48 & 158.25 & 3.289 & 3.165 \\
\hline & $60 \mathrm{~cm}$ & 53.81 & 50.34 & 3.13 & 3.28 & 168.70 & 165.50 & 2.247 & 2.204 \\
\hline \multicolumn{2}{|c|}{ L.S.D at $5 \%$} & NS & 0.638 & 0.081 & 0.044 & 3.326 & 1.597 & 0.099 & 0.035 \\
\hline \multicolumn{10}{|c|}{ Cvs X Foliar applications } \\
\hline \multirow{4}{*}{ Compados } & MLE & 57.72 & 53.46 & 3.17 & 3.35 & 183.55 & 179.55 & 4.424 & 4.338 \\
\hline & Chitosan & 56.69 & 52.62 & 3.13 & 3.31 & 177.66 & 174.55 & 4.287 & 4.214 \\
\hline & Silicon & 55.77 & 52.22 & 3.13 & 3.31 & 175.11 & 172.86 & 4.224 & 4.177 \\
\hline & Control & 51.89 & 46.37 & 3.01 & 3.26 & 156.66 & 151.44 & 3.758 & 3.650 \\
\hline \multirow{4}{*}{ Sugar Snap } & MLE & 36.46 & 32.28 & 4.48 & 4.99 & 163.77 & 161.44 & 3.856 & 3.808 \\
\hline & Chitosan & 35.38 & 31.11 & 4.43 & 4.93 & 157.02 & 153.55 & 3.713 & 3.639 \\
\hline & Silicon & 34.97 & 30.81 & 4.41 & 4.90 & 154.63 & 151.11 & 3.665 & 3.597 \\
\hline & Control & 33.19 & 29.46 & 4.27 & 4.72 & 141.88 & 139.11 & 3.399 & 3.343 \\
\hline \multirow{5}{*}{ Snow Wind } & MLE & 55.34 & 51.02 & 3.10 & 3.28 & 171.84 & 167.55 & 4.115 & 4.002 \\
\hline & Chitosan & 53.42 & 49.29 & 3.09 & 3.23 & 165.14 & 159.55 & 3.936 & 3.802 \\
\hline & Silicon & 53.19 & 49.01 & 3.03 & 3.20 & 161.55 & 157.22 & 3.862 & 3.751 \\
\hline & Control & 50.72 & 46.67 & 2.92 & 3.07 & 148.22 & 143.66 & 3.567 & 3.457 \\
\hline & $5 \%$ & 0.826 & 0.644 & NS & 0.050 & NS & 2.192 & 0.073 & 0.062 \\
\hline \multicolumn{10}{|c|}{ Density X Foliar applications } \\
\hline \multirow{4}{*}{$20 \mathrm{~cm}$} & MLE & 48.60 & 44.27 & 3.44 & 3.74 & 162.11 & 159.44 & 6.484 & 6.377 \\
\hline & Chitosan & 47.52 & 43.06 & 3.38 & 3.68 & 155.84 & 152.66 & 6.233 & 6.106 \\
\hline & Silicon & 47.10 & 42.99 & 3.37 & 3.67 & 154.11 & 151.88 & 6.164 & 6.075 \\
\hline & Control & 44.65 & 40.20 & 3.27 & 3.57 & 141.44 & 138.88 & 5.657 & 5.555 \\
\hline \multirow{4}{*}{$40 \mathrm{~cm}$} & MLE & 49.51 & 45.95 & 3.61 & 3.80 & 173.00 & 167.88 & 3.460 & 3.357 \\
\hline & Chitosan & 48.42 & 44.82 & 3.58 & 3.78 & 168.00 & 162.88 & 3.360 & 3.257 \\
\hline & Silicon & 48.11 & 44.23 & 3.53 & 3.74 & 164.18 & 159.20 & 3.283 & 3.184 \\
\hline & Control & 45.30 & 40.91 & 3.41 & 3.66 & 149.77 & 143.88 & 2.995 & 2.877 \\
\hline \multirow{4}{*}{$60 \mathrm{~cm}$} & MLE & 51.41 & 46.53 & 3.70 & 4.09 & 184.06 & 181.22 & 2.451 & 2.413 \\
\hline & Chitosan & 49.55 & 45.14 & 3.68 & 4.01 & 175.98 & 172.11 & 2.344 & 2.292 \\
\hline & Silicon & 48.73 & 44.81 & 3.68 & 3.99 & 173.00 & 170.11 & 2.304 & 2.265 \\
\hline & Control & 45.85 & 41.38 & 3.51 & 3.82 & 155.55 & 151.44 & 2.072 & 2.017 \\
\hline L.S.D & $5 \%$ & NS & NS & NS & 0.050 & 2.848 & 2.192 & 0.073 & 0.062 \\
\hline
\end{tabular}

S1: 2012/2013 season, S2: 2013/2014 season, MLE: moringa leaf extract and NS: not significant at 0.05 level of significance. 
Table (7): Effect of the triple interaction among cultivars, plant density and foliar applications on yield parameters of sugar pea in the two seasons of 2012/2013 and 2013/2014.

\begin{tabular}{|c|c|c|c|c|c|c|c|c|c|c|}
\hline \multirow{2}{*}{\multicolumn{3}{|c|}{ Treatments }} & \multicolumn{2}{|c|}{$\begin{array}{c}\text { No of } \\
\text { pod } / \text { plant }\end{array}$} & \multicolumn{2}{|c|}{$\begin{array}{l}\text { Average Pod } \\
\text { weight (gm) }\end{array}$} & \multicolumn{2}{|c|}{$\begin{array}{l}\text { Pod yield/plant } \\
(\mathrm{gm})\end{array}$} & \multicolumn{2}{|c|}{$\begin{array}{l}\text { Total pod yield } \\
\text { (ton/fed.) }\end{array}$} \\
\hline & & & S1 & S2 & S1 & S2 & S1 & S2 & s1 & S2 \\
\hline \multirow{12}{*}{ 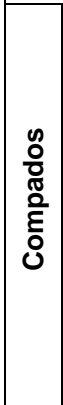 } & & MLE & 56.38 & 52.56 & 3.13 & 3.31 & 176.66 & 174.00 & 7.066 & 6.960 \\
\hline & & Chitosan & 55.87 & 52.11 & 3.06 & 3.23 & 171.33 & 168.66 & 6.853 & 6.746 \\
\hline & & Silicon & 55.10 & 51.85 & 3.06 & 3.23 & 169.00 & 167.66 & 6.760 & 6.706 \\
\hline & & Control & 51.19 & 45.73 & 2.90 & 3.18 & 148.33 & 145.66 & 5.933 & 5.826 \\
\hline & & MLE & 57.20 & 53.53 & 3.20 & 3.35 & 183.33 & 179.33 & 3.666 & 3.586 \\
\hline & & Chitosan & 56.31 & 52.50 & 3.16 & 3.33 & 178.33 & 175.00 & 3.566 & 3.500 \\
\hline & & Silicon & 55.45 & 52.20 & 3.15 & 3.30 & 174.66 & 172.26 & 3.493 & 3.445 \\
\hline & & Control & 51.63 & 46.43 & 3.06 & 3.26 & 158.33 & 151.66 & 3.166 & 3.033 \\
\hline & & MLE & 59.58 & 54.29 & 3.20 & 3.41 & & 185.33 & 2.539 & 2.468 \\
\hline & & Chitosan & 57.89 & 53.25 & 3.16 & 3.38 & $1 \varepsilon$ & 180.00 & 2.442 & 2.397 \\
\hline & $60 \mathrm{c}$ & Silicon & 56.77 & 52.60 & 3.20 & 3.39 & 18 & 178.66 & 2.419 & 2.379 \\
\hline & & Control & 52.85 & 46.96 & 3.09 & 3.34 & & 157.00 & 2.175 & 2.091 \\
\hline \multirow{12}{*}{ 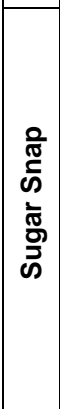 } & & MLE & 35.04 & 31.30 & 4.23 & 4.71 & 148.33 & 147.66 & 5.933 & 5.906 \\
\hline & & Chitosan & 34.55 & 30.44 & 4.14 & 4.65 & 143.33 & 141.66 & 5.733 & 5.666 \\
\hline & & Silicon & 34.27 & 30.35 & 4.13 & 4.65 & & 141.33 & 5.666 & 5.653 \\
\hline & & Control & 32.76 & 29.44 & 4.10 & 4.51 & & 00 & 5.373 & 5.320 \\
\hline & & MLE & 35.60 & 32.28 & 4.48 & 4.80 & & 00 & 3.193 & 3.100 \\
\hline & & Chitosar & 35.19 & 31.54 & 4.43 & 4.76 & & 33 & 3.121 & 3.006 \\
\hline & & Silicon & 35.07 & 31.01 & 4.42 & 4.74 & 155.23 & 147.00 & 3.104 & 2.940 \\
\hline & & Control & 33.23 & 29.46 & 4.25 & 4.68 & 141.33 & 138.00 & 2.826 & 2.760 \\
\hline & & MLE & 38.73 & 33.25 & 4.73 & 5.46 & & 181.66 & 2.442 & 2.419 \\
\hline & & Chitosan & 36.40 & 31.36 & 4.71 & 5.37 & & 66 & 2.286 & 2.246 \\
\hline & & Silicon & 35.56 & 31.07 & 4.69 & 5.31 & 00 & 165.00 & 2.224 & 2.197 \\
\hline & & Control & 33.58 & 29.46 & 4.46 & 4.96 & 0 & 33 & 1.998 & 1.949 \\
\hline \multirow{12}{*}{ 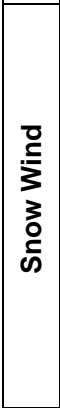 } & & MLE & 54.38 & 48.95 & 2.96 & 3.20 & 33 & 156.66 & 6.453 & 6.266 \\
\hline & & Chitosan & 52.14 & 46.63 & 2.93 & 3.16 & 152.86 & 147.66 & 6.114 & 5.906 \\
\hline & & Silicon & 51.92 & 46.78 & 2.92 & 3.13 & 151.66 & 146.66 & 6.066 & 5.866 \\
\hline & & Control & 50.02 & 45.44 & 2.83 & 3.03 & 141.66 & 138.00 & 5.666 & 5.520 \\
\hline & & MLE & 55.73 & 52.05 & 3.15 & 3.25 & & 169.33 & 3.520 & 3.386 \\
\hline & & Chitosan & 53.75 & 50.43 & 3.15 & 3.24 & & 163.33 & 3.392 & 3.266 \\
\hline & & Silicon & 53.80 & 49.49 & 3.02 & 3.20 & 162.66 & 158.33 & 3.253 & 3.166 \\
\hline & & Control & 51.03 & 46.83 & 2.93 & 3.03 & 149.66 & 142.00 & 2.993 & 2.840 \\
\hline & & MLE & 55.92 & 52.06 & 3.18 & 3.39 & 178.20 & 176.66 & 2.373 & 2.353 \\
\hline & & Chitosan & 54.36 & 50.80 & 3.18 & 3.30 & 172.96 & 167.66 & 2.303 & 2.233 \\
\hline & $\mathbf{c m}$ & Silicon & 53.87 & 50.76 & 3.16 & 3.28 & 170.33 & 166.66 & 2.268 & 2.220 \\
\hline & & Control & 51.11 & 47.74 & 3.00 & 3.16 & 153.33 & 151.00 & 2.042 & 2.011 \\
\hline & LSDo & at $5 \%$ & NS & NS & NS & 0.087 & 4.934 & 3.797 & 0.126 & 0.108 \\
\hline
\end{tabular}

S1: 2012/2013 season, S2: 2013/2014 season, MLE: moringa leaf extract and NS: not significant at 0.05 level of significance.

\section{Pod quality:}

\section{Effect of cultivars:}

Data in Tables (8 and 11) show the effect of cultivars, plant density and foliar applications on pod quality of sugar peas. It is clear in table (8) that Compados cultivar was the superior in pod length in both seasons, whereas Snow Wind cultivar was the superior in pod diameter and Sugar Snap cultivar was the superior in pod thickness in both seasons. In table (11) it could observed that Sugar Snap cultivar was the superior in total soluble 
solids (TSS) and carbohydrates (\%) and the lowest in titrable acidity (\%) in both seasons. While, Snow Wind was the superior in vitamin C $(\mathrm{mg} / 100 \mathrm{~g} \mathrm{fw})$ in both seasons. Similar results were obtained by El-Desuki (2006) and Tewfik (2014).

Table (8): Effect of cultivars, plant density and foliar applications on pod parameters of sugar pea in the two seasons of 2012/2013 and 2013/2014.

\begin{tabular}{|c|c|c|c|c|c|c|c|}
\hline \multirow{2}{*}{\multicolumn{2}{|c|}{ Treatments }} & \multicolumn{2}{|c|}{ Pod length $(\mathrm{cm})$} & \multicolumn{2}{|c|}{$\begin{array}{l}\text { Pod diameter } \\
(\mathrm{mm})\end{array}$} & \multicolumn{2}{|c|}{$\begin{array}{c}\text { Pod thickness } \\
(\mathrm{mm})\end{array}$} \\
\hline & & S1 & S2 & S1 & S2 & S1 & S2 \\
\hline \multirow{3}{*}{ Cvs. } & Compados & 9.09 & 9.64 & 17.56 & 18.26 & 3.23 & 3.58 \\
\hline & Sugar Snap & 8.11 & 8.35 & 15.11 & 15.43 & 8.47 & 10.50 \\
\hline & Snow Wind & 8.75 & 8.70 & 18.17 & 18.90 & 3.05 & 3.32 \\
\hline \multicolumn{2}{|c|}{ L.S.D at $5 \%$} & 0.131 & 0.121 & 0.274 & 0.173 & 0.288 & 0.251 \\
\hline \multirow{3}{*}{ Density } & $20 \mathrm{~cm}$ & 8.41 & 8.73 & 16.45 & 17.27 & 4.64 & 5.55 \\
\hline & $40 \mathrm{~cm}$ & 8.64 & 8.86 & 17.04 & 17.52 & 4.95 & 5.78 \\
\hline & $60 \mathrm{~cm}$ & 8.91 & 9.10 & 17.35 & 17.80 & 5.17 & 6.07 \\
\hline \multicolumn{2}{|c|}{ L.S.D at $5 \%$} & 0.176 & 0.138 & 0.181 & 0.193 & 0.240 & 0.167 \\
\hline \multirow{4}{*}{ Foliar } & MLE & 9.00 & 9.15 & 17.10 & 17.87 & 5.12 & 6.05 \\
\hline & Chitosan & 8.72 & 8.97 & 17.30 & 17.57 & 5.02 & 5.98 \\
\hline & Silicon & 8.64 & 8.91 & 16.93 & 17.65 & 5.00 & 5.95 \\
\hline & Control & 8.26 & 8.56 & 16.45 & 17.03 & 4.53 & 5.23 \\
\hline \multicolumn{2}{|c|}{ L.S.D at $5 \%$} & 0.180 & 0.146 & 0.219 & 0.244 & 0.192 & 0.175 \\
\hline
\end{tabular}

S1: 2012/2013 season, S2: 2013/2014 season and MLE: moringa leaf extract.

\section{Effect of plant density:}

Data in Tables (8 and 11) indicated that all tested densities were affected pod length, pod diameter, pod thickness, total soluble solids (TSS), vitamin C, titrable acidity (\%) and carbohydrates (\%) in both seasons. The superior density was $60 \mathrm{~cm}$ among plants, while the lowest was $20 \mathrm{~cm}$ among plants in both seasons. Similar results were obtained by Shaukat et al. (2012) on pea, they reported that maximum pod length was recorded in $(50 \mathrm{~cm})$ row spacing while minimum pod length was measured in $(30 \mathrm{~cm})$ row spacing.

\section{Effect of foliar applications:}

Also, Tables ( 8 and 11$)$ showed that all foliar applications, i.e., moringa leaf extract, chitosan and silicon significantly affected pod length, pod diameter, pod thickness, total soluble solids (TSS), vitamin C, titrable acidity (\%) and carbohydrates (\%) in both seasons. The best application in all studied parameters was obtained when sugar pea plants sprayed with moringa leaf extract followed by chitosan and silicon, respectively except pod diameter in the first season whereas chitosan was the best one. Concerning vitamin $\mathrm{C}$, foliar spray with moringa leaf extract was the superior in the first season while silicon was the superior in the second season followed by moringa leaf extract and chitosan, respectively. The lowest application in all studied parameters was control except titrable acidity where it was higher compare with other applications.

Table(9): Effect of the dual interaction between cultivar and density, cultivar and foliar applications and density and foliar 
applications on pod parameters of sugar pea in the two seasons of 2012/2013 and 2013/2014.

\begin{tabular}{|c|c|c|c|c|c|c|c|}
\hline \multirow{2}{*}{\multicolumn{2}{|c|}{ Treatments }} & \multicolumn{2}{|c|}{ Pod length (cm) } & \multicolumn{2}{|c|}{$\begin{array}{c}\text { Pod diameter } \\
(\mathrm{mm})\end{array}$} & \multicolumn{2}{|c|}{ Pod thickness (mm) } \\
\hline & & S1 & S2 & S1 & S2 & S1 & S2 \\
\hline \multicolumn{8}{|c|}{ Cvs X Density } \\
\hline \multirow{3}{*}{ Compados } & $20 \mathrm{~cm}$ & 8.86 & 9.43 & 17.35 & 17.85 & 3.13 & 3.33 \\
\hline & $40 \mathrm{~cm}$ & 9.08 & 9.60 & 17.55 & 18.18 & 3.29 & 3.58 \\
\hline & $60 \mathrm{~cm}$ & 9.34 & 9.89 & 17.78 & 18.74 & 3.26 & 3.83 \\
\hline \multirow{3}{*}{ Sugar Snap } & $20 \mathrm{~cm}$ & 7.81 & 8.24 & 14.59 & 15.36 & 7.90 & 10.28 \\
\hline & $40 \mathrm{~cm}$ & 8.04 & 8.28 & 15.27 & 15.39 & 8.48 & 10.45 \\
\hline & $60 \mathrm{~cm}$ & 8.49 & 8.53 & 15.47 & 15.55 & 9.04 & 10.79 \\
\hline \multirow{3}{*}{ Snow Wind } & $20 \mathrm{~cm}$ & 8.57 & 8.52 & 17.41 & 18.60 & 2.89 & 3.05 \\
\hline & $40 \mathrm{~cm}$ & 8.79 & 8.71 & 18.29 & 19.00 & 3.07 & 3.32 \\
\hline & $60 \mathrm{~cm}$ & 8.91 & 8.89 & 18.80 & 19.11 & 3.21 & 3.60 \\
\hline \multicolumn{2}{|c|}{ L.S.D at $5 \%$} & NS & NS & 0.313 & NS & 0.416 & NS \\
\hline \multicolumn{8}{|c|}{ Cvs X Foliar applications } \\
\hline \multirow{4}{*}{ Compados } & MLE & 9.39 & 9.95 & 17.71 & 18.75 & 3.36 & 3.75 \\
\hline & Chitosan & 9.23 & 9.69 & 17.80 & 18.33 & 3.25 & 3.77 \\
\hline & Silicon & 9.18 & 9.61 & 17.59 & 18.34 & 3.25 & 3.69 \\
\hline & Control & 8.58 & 9.31 & 17.13 & 17.62 & 3.05 & 3.12 \\
\hline \multirow{4}{*}{ Sugar Snap } & MLE & 8.34 & 8.60 & 15.45 & 15.77 & 8.80 & 10.84 \\
\hline & Chitosan & 8.19 & 8.51 & 15.42 & 15.40 & 8.66 & 10.83 \\
\hline & Silicon & 8.07 & 8.31 & 15.04 & 15.51 & 8.67 & 10.63 \\
\hline & Control & 7.86 & 7.98 & 14.53 & 15.05 & 7.76 & 9.72 \\
\hline \multirow{4}{*}{ Snow Wind } & MLE & 9.26 & 8.90 & 18.15 & 19.10 & 3.19 & 3.55 \\
\hline & Chitosan & 8.74 & 8.72 & 18.67 & 18.99 & 3.14 & 3.35 \\
\hline & Silicon & 8.68 & 8.82 & 18.15 & 19.12 & 3.09 & 3.54 \\
\hline & Control & 8.33 & 8.39 & 17.69 & 18.41 & 2.79 & 2.86 \\
\hline \multicolumn{2}{|c|}{ L.S.D at $5 \%$} & NS & NS & NS & NS & 0.333 & NS \\
\hline \multicolumn{8}{|c|}{ Density X Foliar applications } \\
\hline \multirow{4}{*}{$20 \mathrm{~cm}$} & MLE & 8.74 & 8.89 & 16.58 & 17.63 & 4.81 & 5.88 \\
\hline & Chitosan & 8.41 & 8.82 & 16.84 & 17.44 & 4.72 & 5.82 \\
\hline & Silicon & 8.43 & 8.75 & 16.39 & 17.37 & 4.63 & 5.74 \\
\hline & Control & 8.07 & 8.46 & 15.99 & 16.65 & 4.40 & 4.77 \\
\hline \multirow{4}{*}{$40 \mathrm{~cm}$} & MLE & 8.95 & 9.08 & 17.25 & 17.78 & 5.12 & 6.00 \\
\hline & Chitosan & 8.67 & 8.92 & 17.39 & 17.50 & 5.13 & 5.92 \\
\hline & Silicon & 8.64 & 8.93 & 17.03 & 17.65 & 5.07 & 5.89 \\
\hline & Control & 8.28 & 8.53 & 16.48 & 17.16 & 4.47 & 5.33 \\
\hline \multirow{4}{*}{$60 \mathrm{~cm}$} & MLE & 9.30 & 9.48 & 17.48 & 18.22 & 5.43 & 6.25 \\
\hline & Chitosan & 9.08 & 9.18 & 17.67 & 17.79 & 5.20 & 6.21 \\
\hline & Silicon & 8.86 & 9.05 & 17.37 & 17.94 & 5.30 & 6.23 \\
\hline & Control & 8.42 & 8.69 & 16.88 & 17.27 & 4.73 & 5.60 \\
\hline L.S.D & $5 \%$ & NS & NS & NS & NS & NS & NS \\
\hline
\end{tabular}

S1: 2012/2013 season, S2: $2013 / 2014$ season, MLE: moringa leaf extract and NS: not significant at 0.05 level of significance.

These results were agreed with those obtained by Farouk and Ramadan (2012) on cowpea; El-Miniawy et al. (2013) on strawberry and Abu-Muriefah (2013) on common bean for chitosan and Toresano- Sanchez et al. (2010) on watermelon for silicon. In this respect Ghoname et al. (2010) on pepper found that chitosan application improved pepper quality and increased TSS and vitamin C contents. Moreover, Jia et al. (2011) reported that silicon fertilizer could enhance hardness and pressure-resistance of tomato and increase vitamin $C$ of strawberry and eggplant. The possible mechanisms of silicon-improvement of crop quality were summarized in the following aspects: silicon provision, improvement of micro-nutrient supply, coordination of nutrition supply and enhancement of resistance to stressful conditions. 
Table(10): Effect of the triple interaction among cultivars, plant density and foliar applications on pod parameters of sugar pea cultivars in the two seasons of $2012 / 2013$ and $2013 / 2014$.

\begin{tabular}{|c|c|c|c|c|c|c|c|c|}
\hline \multicolumn{3}{|c|}{ Treatments } & \multicolumn{2}{|c|}{ Pod length $(\mathrm{cm})$} & \multicolumn{2}{|c|}{ Pod diameter (mm) } & \multicolumn{2}{|c|}{$\begin{array}{c}\text { Pod thickness } \\
(\mathrm{mm})\end{array}$} \\
\hline \multirow{13}{*}{ 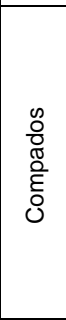 } & \multirow{5}{*}{$20 \mathrm{~cm}$} & & & & & & & \\
\hline & & JMIF & 920 & 949 & 1757 & 1829 & 321 & 358 \\
\hline & & Chitosan & 8.77 & 9.52 & 17.50 & $\frac{10.29}{18.10}$ & $\frac{0.21}{3.20}$ & 3.00 \\
\hline & & Silicon & 9.05 & 9.45 & 17.32 & 17.74 & 3.16 & 3.46 \\
\hline & & Control & 8.41 & 9.26 & 17.00 & 17.28 & 2.94 & 2.66 \\
\hline & \multirow{5}{*}{$40 \mathrm{~cm}$} & MLE & 9.27 & 9.81 & 17.76 & 17.48 & 3.41 & 3.68 \\
\hline & & Chitosan & 9.24 & 9.73 & 17.88 & 18.13 & 3.33 & 3.66 \\
\hline & & Silicon & 9.20 & 9.62 & 17.61 & 18.43 & 3.45 & 3.65 \\
\hline & & Control & 8.61 & 9.27 & 16.96 & 17.67 & 2.99 & 3.35 \\
\hline & & MLE & 9.70 & 10.56 & 17.81 & 19.47 & 3.46 & 4.00 \\
\hline & \multirow{3}{*}{$60 \mathrm{~cm}$} & Chitosan & 9.66 & 9.82 & 18.01 & 18.75 & 3.22 & 4.02 \\
\hline & & Silicon & 9.28 & 9.76 & 17.85 & 18.85 & 3.13 & 3.96 \\
\hline & & Control & 8.73 & 9.41 & 17.44 & 17.91 & 3.23 & 3.36 \\
\hline \multirow{12}{*}{$\begin{array}{l}\text { 음 } \\
\text { ஸ } \\
\text { స్ } \\
\text { ত্ } \\
\text { क }\end{array}$} & \multirow{4}{*}{$20 \mathrm{~cm}$} & MLE & 7.94 & 8.51 & 14.75 & 15.71 & 8.20 & 10.67 \\
\hline & & Chitosan & 7.83 & 8.38 & 14.78 & 15.30 & 8.03 & 10.64 \\
\hline & & Silicon & 7.83 & 8.22 & 14.58 & 15.41 & 7.77 & 10.39 \\
\hline & & Control & 7.64 & 7.84 & 14.23 & 15.02 & 7.59 & 9.43 \\
\hline & \multirow{4}{*}{$40 \mathrm{~cm}$} & MLE & 8.27 & 8.56 & 15.61 & 15.75 & 8.78 & 10.83 \\
\hline & & Chitosan & 8.04 & 8.42 & 15.72 & 15.35 & 8.71 & 10.91 \\
\hline & & Silicon & 7.96 & 8.25 & 15.15 & 15.40 & 8.82 & 10.51 \\
\hline & & Control & 7.90 & 7.90 & 14.61 & 15.05 & 7.62 & 9.53 \\
\hline & \multirow{4}{*}{$60 \mathrm{~cm}$} & MLE & 8.81 & 8.74 & 15.97 & 15.85 & 9.43 & 11.02 \\
\hline & & Chitosan & 8.72 & 8.73 & 15.77 & 15.56 & 9.24 & 10.93 \\
\hline & & Silicon & 8.41 & 8.45 & 15.39 & 15.71 & 9.41 & 10.99 \\
\hline & & Control & 8.04 & 8.20 & 14.74 & 15.10 & 8.08 & 10.20 \\
\hline \multirow{12}{*}{ 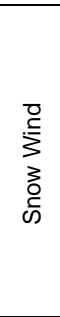 } & \multirow{4}{*}{$20 \mathrm{~cm}$} & MLE & 9.07 & 8.67 & 17.42 & 18.88 & 3.01 & 3.40 \\
\hline & & Chitosan & 8.63 & 8.56 & 18.23 & 18.91 & 2.91 & 3.18 \\
\hline & & Silicon & 8.41 & 8.57 & 17.26 & 18.97 & 2.97 & 3.38 \\
\hline & & Control & 8.16 & 8.27 & 16.75 & 17.66 & 2.67 & 2.24 \\
\hline & \multirow{4}{*}{$40 \mathrm{~cm}$} & MLE & 9.32 & 8.88 & 18.37 & 19.10 & 3.17 & 3.50 \\
\hline & & Chitosan & 8.73 & 8.61 & 18.58 & 19.01 & 3.37 & 3.19 \\
\hline & & Silicon & 8.76 & 8.93 & 18.32 & 19.11 & 2.93 & 3.50 \\
\hline & & Control & 8.33 & 8.42 & 17.87 & 18.77 & 2.80 & 3.10 \\
\hline & \multirow{4}{*}{$60 \mathrm{~cm}$} & MLE & 9.38 & 9.14 & 18.67 & 19.33 & 3.40 & 3.74 \\
\hline & & Chitosan & 8.86 & 8.99 & 19.22 & 19.05 & 3.16 & 3.69 \\
\hline & & Silicon & 8.88 & 8.94 & 18.86 & 19.27 & 3.36 & 3.75 \\
\hline & & Control & 8.51 & 8.48 & 18.45 & 18.80 & 2.90 & 3.24 \\
\hline \multicolumn{3}{|c|}{ LSD at $5 \%$} & NS & $\mathrm{NS}$ & NS & $\mathrm{NS}$ & NS & $\mathrm{NS}$ \\
\hline
\end{tabular}

S1: 2012/2013 season, S2: 2013/2014 season, MLE: moringa leaf extract and NS: not significant at 0.05 level of significance.

Table (11): Effect of cultivars, plant density and foliar applications on pod quality parameters of sugar pea in the two seasons of 2012/2013 and 2013/2014.

\begin{tabular}{|c|c|c|c|c|c|c|c|c|c|}
\hline \multirow{2}{*}{\multicolumn{2}{|c|}{ Treatments }} & \multicolumn{2}{|c|}{ TSS } & \multicolumn{2}{|c|}{$\begin{array}{c}\text { Vitamin C } \\
(\mathrm{mg} / 100 \mathrm{gfw})\end{array}$} & \multicolumn{2}{|c|}{ Acidity (\%) } & \multicolumn{2}{|c|}{$\begin{array}{c}\text { Carbohydrates } \\
(\%)\end{array}$} \\
\hline & & S1 & S2 & S1 & S2 & S1 & S2 & S1 & S2 \\
\hline \multirow{3}{*}{ Cvs. } & Compados & 7.88 & 10.01 & 68.57 & 75.23 & 0.434 & 0.413 & 44.23 & 45.65 \\
\hline & Sugar Snap & 8.72 & 10.02 & 74.83 & 79.03 & 0.349 & 0.361 & 57.33 & 58.61 \\
\hline & Snow Wind & 7.79 & 9.28 & 78.90 & 96.30 & 0.388 & 0.405 & 46.34 & 49.12 \\
\hline \multicolumn{2}{|c|}{ L.S.D at $5 \%$} & 0.239 & 0.274 & 2.194 & 1.047 & 0.010 & 0.020 & 0.348 & 0.223 \\
\hline \multirow{3}{*}{ Density } & $20 \mathrm{~cm}$ & 7.65 & 9.25 & 72.57 & 87.35 & 0.417 & 0.416 & 46.05 & 47.73 \\
\hline & $40 \mathrm{~cm}$ & 8.20 & 9.86 & 74.40 & 82.66 & 0.382 & 0.390 & 49.87 & 51.54 \\
\hline & $60 \mathrm{~cm}$ & 8.54 & 10.21 & 75.32 & 89.37 & 0.371 & 0.373 & 51.98 & 54.12 \\
\hline \multicolumn{2}{|c|}{ L.S.D at $5 \%$} & 0.152 & 0.157 & 1.204 & 2.069 & 0.008 & 0.011 & 0.345 & 0.141 \\
\hline \multirow{4}{*}{ Foliar } & MLE & 8.42 & 10.05 & 77.33 & 86.84 & 0.378 & 0.383 & 52.53 & 54.43 \\
\hline & Chitosan & 8.24 & 9.85 & 76.28 & 85.37 & 0.386 & 0.389 & 50.26 & 51.75 \\
\hline & Silicon & 8.17 & 9.80 & 75.91 & 87.26 & 0.381 & 0.388 & 49.39 & 50.97 \\
\hline & Control & 7.70 & 9.39 & 66.86 & 74.60 & 0.416 & 0.412 & 45.02 & 47.35 \\
\hline \multicolumn{2}{|c|}{ L.S.D at $5 \%$} & 0.158 & 0.152 & 1.658 & 1.442 & 0.008 & 0.012 & 0.400 & 0.178 \\
\hline
\end{tabular}

S1: 2012/2013 season, S2: 2013/2014 season and MLE: moringa leaf extract. 


\section{Effect of interactions:}

The effect of interactions on pod length, pod diameter, pod thickness, vitamin C, titrable acidity (\%) and carbohydrates (\%) was presented in Tables $(9,10,12$ and 13). The effect of interactions was insignificant on pod length, pod diameter except (cultivars $\times$ density) in the first season and pod thickness except (cultivars $\times$ density) and (cultivars $\times$ foliar applications) in the first season. Concerning, total soluble solids (TSS), vitamin C, titrable acidity (\%) and carbohydrates (\%), Tables (12 and 13) indicated that the effect of interactions was insignificant on total soluble solids (TSS) except (cultivars $\times$ density) in the second season and (cultivars $\times$ foliar applications) in the first season,

Table (12): Effect of the dual interaction between cultivar and density, cultivar and foliar applications and density and foliar applications on pod quality parameters of sugar pea in the two seasons of 2012/2013 and 2013/2014.

\begin{tabular}{|c|c|c|c|c|c|c|c|c|c|}
\hline \multirow{2}{*}{\multicolumn{2}{|c|}{ Treatments }} & \multicolumn{2}{|c|}{ TSS } & \multicolumn{2}{|c|}{ Vitamin C (mg/100gfw) } & \multicolumn{2}{|c|}{ Acidity (\%) } & \multicolumn{2}{|c|}{ Carbohydrates (\%) } \\
\hline & & S1 & $\mathbf{S 2}$ & S1 & S2 & S1 & S2 & S1 & S2 \\
\hline \multicolumn{10}{|c|}{ Cvs X Density } \\
\hline \multirow{3}{*}{ Compados } & $20 \mathrm{~cm}$ & 7.36 & 9.49 & 66.70 & 72.09 & 0.455 & 0.437 & 42.93 & 44.39 \\
\hline & $40 \mathrm{~cm}$ & 8.03 & 10.12 & 68.81 & 74.35 & 0.429 & 0.415 & 44.38 & 45.58 \\
\hline & $60 \mathrm{~cm}$ & 8.24 & 10.43 & 70.20 & 79.25 & 0.419 & 0.386 & 45.38 & 46.99 \\
\hline \multirow{3}{*}{ Sugar Snap } & $20 \mathrm{~cm}$ & 8.27 & 9.31 & 73.71 & 77.05 & 0.376 & 0.392 & 51.28 & 51.60 \\
\hline & $40 \mathrm{~cm}$ & 8.61 & 10.25 & 74.69 & 78.16 & 0.339 & 0.349 & 58.32 & 59.53 \\
\hline & $60 \mathrm{~cm}$ & 9.29 & 10.50 & 76.09 & 81.88 & 0.331 & 0.344 & 62.40 & 64.70 \\
\hline \multirow{3}{*}{ Snow Wind } & $20 \mathrm{~cm}$ & 7.31 & 8.94 & 77.30 & 92.50 & 0.420 & 0.420 & 43.95 & 47.20 \\
\hline & $40 \mathrm{~cm}$ & 7.97 & 9.20 & 79.71 & 95.49 & 0.380 & 0.407 & 46.91 & 49.50 \\
\hline & $60 \mathrm{~cm}$ & 8.10 & 9.70 & 79.68 & 100.91 & 0.365 & 0.390 & 48.16 & 50.67 \\
\hline \multicolumn{2}{|c|}{ L.S.D at $5 \%$} & NS & 0.272 & NS & NS & NS & NS & 0.598 & 0.245 \\
\hline \multicolumn{10}{|c|}{ Cvs X Foliar applications } \\
\hline \multirow{4}{*}{ Compados } & MLE & 8.07 & 10.43 & 71.38 & 78.78 & 0.430 & 0.404 & 47.80 & 53.77 \\
\hline & Chitosan & 7.91 & 10.05 & 70.57 & 76.42 & 0.431 & 0.409 & 44.39 & 48.48 \\
\hline & Silicon & 7.94 & 9.96 & 70.32 & 78.73 & 0.428 & 0.409 & 44.28 & 47.46 \\
\hline & Control & 7.58 & 9.61 & 62.00 & 67.00 & 0.448 & 0.429 & 40.45 & 43.44 \\
\hline \multirow{4}{*}{ Sugar Snap } & MLE & 9.18 & 10.27 & 77.85 & 81.25 & 0.340 & 0.353 & 60.22 & 74.66 \\
\hline & Chitosan & 8.97 & 10.08 & 76.56 & 80.81 & 0.347 & 0.355 & 59.09 & 71.81 \\
\hline & Silicon & 8.76 & 10.10 & 77.24 & 81.79 & 0.341 & 0.356 & 58.07 & 69.82 \\
\hline & Control & 7.97 & 9.63 & 67.66 & 72.27 & 0.368 & 0.383 & 51.96 & 64.03 \\
\hline \multirow{4}{*}{ Snow Wind } & MLE & 8.00 & 9.45 & 82.77 & 100.50 & 0.366 & 0.394 & 49.58 & 58.74 \\
\hline & Chitosan & 7.83 & 9.41 & 80.60 & 98.88 & 0.382 & 0.404 & 47.28 & 51.61 \\
\hline & Silicon & 7.81 & 9.33 & 81.28 & 101.27 & 0.373 & 0.400 & 45.84 & 49.64 \\
\hline & Control & 7.54 & 8.94 & 70.93 & 84.54 & 0.431 & 0.424 & 42.66 & 49.25 \\
\hline \multicolumn{2}{|c|}{ L.S.D at $5 \%$} & 0.273 & NS & NS & 2.498 & 0.014 & NS & 0.693 & 0.309 \\
\hline \multicolumn{10}{|c|}{ Density X Foliar applications } \\
\hline \multirow{4}{*}{$20 \mathrm{~cm}$} & MLE & 7.94 & 9.47 & 75.22 & 83.55 & 0.410 & 0.407 & 48.22 & 49.64 \\
\hline & Chitosan & 7.72 & 9.28 & 73.37 & 81.37 & 0.415 & 0.413 & 46.93 & 48.34 \\
\hline & Silicon & 7.72 & 9.23 & 74.60 & 83.88 & 0.412 & 0.412 & 46.45 & 48.71 \\
\hline & Control & 7.22 & 9.00 & 67.08 & 73.38 & 0.432 & 0.433 & 42.61 & 44.22 \\
\hline \multirow{4}{*}{$40 \mathrm{~cm}$} & MLE & 8.45 & 10.10 & 77.78 & 85.54 & 0.370 & 0.380 & 53.14 & 55.01 \\
\hline & Chitosan & 8.34 & 9.98 & 76.80 & 84.92 & 0.378 & 0.388 & 51.14 & 52.31 \\
\hline & Silicon & 8.24 & 9.92 & 76.37 & 86.10 & 0.369 & 0.383 & 49.50 & 50.62 \\
\hline & Control & 7.78 & 9.44 & 66.66 & 74.11 & 0.413 & 0.411 & 45.70 & 48.21 \\
\hline \multirow{4}{*}{$60 \mathrm{~cm}$} & MLE & 8.86 & 10.58 & 79.01 & 91.44 & 0.355 & 0.363 & 56.23 & 58.66 \\
\hline & Chitosan & 8.65 & 10.27 & 77.56 & 89.82 & 0.367 & 0.367 & 52.69 & 54.61 \\
\hline & Silicon & 8.55 & 10.24 & 77.87 & 91.82 & 0.362 & 0.370 & 52.24 & 53.57 \\
\hline & Control & 8.10 & 9.74 & 66.88 & 76.32 & 0.402 & 0.393 & 46.76 & 49.63 \\
\hline \multicolumn{2}{|c|}{ L.S.D at $5 \%$} & NS & NS & NS & 2.498 & NS & NS & 0.693 & 0.309 \\
\hline
\end{tabular}

S1: 2012/2013 season, S2: 2013/2014 season, MLE: moringa leaf extract and NS: not significant at 0.05 level of significance. 
vitamin C except (cultivars $\times$ foliar applications) and (density $\times$ foliar applications) in the second season and titrable acidity (\%) except (cultivars $\times$ foliar applications) in the first season. On the other hand, the effect of all interactions on carbohydrates (\%) was significant in both seasons. Generally, the superior interaction in pod length and pod diameter was (Compados $\times 60$ $\mathrm{cm} \times$ moringa leaf extract) in both seasons except pod diameter in the first season which (Compados $\times 60 \mathrm{~cm} \times$ chitosan) was the superior. Moreover, (Sugar Snap $\times 60 \mathrm{~cm} \times$ moringa leaf extract) was the best interaction in pod thickness, total soluble solids (TSS), titrable acidity (\%) and carbohydrates (\%) in both seasons. Meanwhile, the best one in vitamin C was (Snow Wind $\times 60 \mathrm{~cm} \times$ moringa leaf extract) in both seasons.

Table (13): Effect of the triple interaction among cultivars, plant density and foliar applications on pod quality parameters of sugar pea in the two seasons of 2012/2013 and 2013/2014.

\begin{tabular}{|c|c|c|c|c|c|c|c|c|c|c|}
\hline \multicolumn{3}{|c|}{ Treatments } & \multicolumn{2}{|c|}{ TSS } & \multicolumn{2}{|c|}{$\begin{array}{c}\text { Vitamin C } \\
(\mathrm{mg} / 100 \mathrm{~g} \mathrm{fw})\end{array}$} & \multicolumn{2}{|c|}{ Acidity (\%) } & \multicolumn{2}{|c|}{$\begin{array}{c}\text { Carbohydrates } \\
(\%)\end{array}$} \\
\hline & & & S1 & S2 & S1 & S2 & S1 & S2 & S1 & S2 \\
\hline \multirow{12}{*}{ 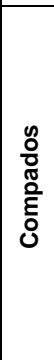 } & \multirow{4}{*}{$20 \mathrm{~cm}$} & MLE & 7.43 & 10.00 & 69.16 & 76.22 & 0.446 & 0.430 & 45.63 & 46.46 \\
\hline & & Chitosan & 7.40 & 9.46 & 67.83 & 71.33 & 0.456 & 0.433 & 43.12 & 43.61 \\
\hline & & Silicon & 7.56 & 9.33 & 68.13 & 75.67 & 0.450 & 0.433 & 43.60 & 46.23 \\
\hline & & Control & 7.06 & 9.16 & 61.66 & 65.16 & 0.470 & 0.453 & 39.36 & 41.26 \\
\hline & \multirow{4}{*}{$40 \mathrm{~cm}$} & MLE & 8.26 & 10.46 & 71.85 & 77.46 & 0.430 & 0.404 & 48.10 & 49.38 \\
\hline & & Chitosan & 8.03 & 10.20 & 71.73 & 76.60 & 0.420 & 0.411 & 44.16 & 45.72 \\
\hline & & Silicon & 8.06 & 10.16 & 70.33 & 77.33 & 0.420 & 0.410 & 44.50 & 45.01 \\
\hline & & Control & 7.76 & 9.66 & 61.33 & 66.00 & 0.446 & 0.436 & 40.76 & 42.24 \\
\hline & \multirow{4}{*}{$60 \mathrm{~cm}$} & MLE & 8.53 & 10.83 & 73.13 & 82.66 & 0.413 & 0.380 & 49.66 & 51.53 \\
\hline & & Chitosan & 8.30 & 10.50 & 72.16 & 81.33 & 0.416 & 0.383 & 45.89 & 47.02 \\
\hline & & Silicon & 8.20 & 10.40 & 72.50 & 83.20 & 0.416 & 0.384 & 44.75 & 46.64 \\
\hline & & Control & 7.93 & 10.00 & 63.00 & 69.83 & 0.430 & 0.400 & 41.23 & 42.77 \\
\hline \multirow{12}{*}{ 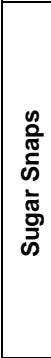 } & \multirow{4}{*}{$20 \mathrm{~cm}$} & MLE & 8.73 & 9.40 & 75.70 & 78.26 & 0.375 & 0.386 & 53.63 & 53.63 \\
\hline & & Chitosan & 8.46 & 9.33 & 73.63 & 77.46 & 0.365 & 0.389 & 53.08 & 53.57 \\
\hline & & Silicon & 8.30 & 9.36 & 75.66 & 78.98 & 0.376 & 0.389 & 51.92 & 52.43 \\
\hline & & Control & 7.60 & 9.16 & 69.86 & 73.49 & 0.388 & 0.403 & 46.48 & 46.75 \\
\hline & \multirow{4}{*}{$40 \mathrm{~cm}$} & MLE & 9.00 & 10.50 & 78.23 & 80.50 & 0.324 & 0.340 & 60.93 & 62.34 \\
\hline & & Chitosan & 8.96 & 10.43 & 77.66 & 80.50 & 0.342 & 0.340 & 60.70 & 61.24 \\
\hline & & Silicon & 8.66 & 10.43 & 77.26 & 80.80 & 0.326 & 0.340 & 58.00 & 59.17 \\
\hline & & Control & 7.83 & 9.66 & 65.60 & 70.86 & 0.362 & 0.378 & 53.66 & 55.38 \\
\hline & \multirow{4}{*}{$60 \mathrm{~cm}$} & MLE & 9.83 & 10.93 & 79.63 & 85.00 & 0.320 & 0.330 & 66.10 & 68.69 \\
\hline & & Chitosan & 9.50 & 10.50 & 78.40 & 84.46 & 0.333 & 0.336 & 63.50 & 66.60 \\
\hline & & Silicon & 9.33 & 10.50 & 78.80 & 85.60 & 0.320 & 0.340 & 64.29 & 65.05 \\
\hline & & Control & 8.50 & 10.06 & 67.53 & 72.46 & 0.353 & 0.370 & 55.73 & 58.45 \\
\hline \multirow{12}{*}{$\begin{array}{l}\text { D } \\
\text { 立 } \\
3 \\
\text { o } \\
\text { ஸे }\end{array}$} & \multirow{4}{*}{$20 \mathrm{~cm}$} & MLE & 7.66 & 9.03 & 80.80 & 96.16 & 0.410 & 0.406 & 45.40 & 48.83 \\
\hline & & Chitosan & 7.30 & 9.06 & 78.66 & 95.33 & 0.423 & 0.416 & 44.60 & 47.84 \\
\hline & & Silicon & 7.30 & 9.00 & 80.00 & 97.00 & 0.410 & 0.414 & 43.83 & 47.47 \\
\hline & & Control & 7.00 & 8.66 & 69.73 & 81.50 & 0.440 & 0.443 & 41.98 & 44.66 \\
\hline & \multirow{4}{*}{$40 \mathrm{~cm}$} & MLE & 8.10 & 9.33 & 83.26 & 98.66 & 0.356 & 0.396 & 50.41 & 53.31 \\
\hline & & Chitosan & 8.03 & 9.33 & 81.00 & 97.66 & 0.371 & 0.413 & 48.56 & 49.98 \\
\hline & & Silicon & 8.00 & 9.16 & 81.53 & 100.16 & 0.361 & 0.400 & 46.01 & 47.69 \\
\hline & & Control & 7.76 & 9.00 & 73.06 & 85.46 & 0.432 & 0.420 & 42.66 & 47.01 \\
\hline & \multirow{4}{*}{$60 \mathrm{~cm}$} & MLE & 8.23 & 10.00 & 84.26 & 106.66 & 0.333 & 0.380 & 52.93 & 55.76 \\
\hline & & Chitosan & 8.16 & 9.83 & 82.13 & 103.66 & 0.353 & 0.383 & 48.70 & 50.21 \\
\hline & & Silicon & 8.13 & 9.83 & 82.33 & 106.66 & 0.350 & 0.386 & 47.68 & 49.03 \\
\hline & & Control & 7.86 & 9.16 & 70.00 & 86.66 & 0.423 & 0.410 & 43.33 & 47.68 \\
\hline & \multicolumn{2}{|c|}{ LSD at $5 \%$} & NS & NS & NS & NS & NS & NS & 1.200 & 0.535 \\
\hline
\end{tabular}

S1: 2012/2013 season, S2: $2013 / 2014$ season, MLE: moringa leaf extract and NS: not significant at 0.05 level of significance. 


\section{CONCLUSION}

It could be concluded that Compados cultivar was the highest pod yield/plant, and total yield/fed. when cultivated on $20 \mathrm{~cm}$ apart, meanwhile Sugar Snap cultivars gave the best pod quality when cultivated on $60 \mathrm{~cm}$ apart and sprayed with moringa leaf extract three times, i.e., 15 days after planting then repeated each 15 days interval, respectively.

\section{REFRENECES}

Abou-Baker, N.H.; M. Abd-Eladl and M.M. Abbas (2011). Use of silicate and different cultivation practices in alleviating salt stress effect on bean plants. Aust.J.Basic \& Appl.Sci., 5(9): 769-781.

Abu-Muriefah, S.S. (2013). Effect of chitosan on common bean (Phaseolus vulgaris L.) plants grown under water stress conditions. Int.Res.J.Agric.Sci.Soil Sci., 3(6): 192-199.

Agurie, S.; W. Agara; F. Kubota and P.B. Kaufman (1992). Physiological role of silicon in photosynthesis and dry matter production in rice plants. Jpn.J.Crop Sci., 61: 200-206.

A.O.A.C. (1990). Association of Official Agricultural Chemists. Methods of analysis, $15^{\text {th }}$ edition, Washington, D.C. USA.

Aziz, T.; M.A. Gill and Rahmatullah (2002). Silicon nutrition and crop production: a review. Pak. J. Agri. Sa., 39(3):181-187.

Azpilicueta M.; I. Irigoyen; B. Lasa; J. Muro and P. M. Aparicio-Tejo (2012). Yield and quality of sugar snap pea in the Ebro Valley: Sowing date and seed density. Sci.Agric.,69(5): 320-326.

Bakry, B.A.; T.A. Elewa; M.F. El Karamany; M.S. Zeidan and M.M. Tawfik (2011). Effect of row spacing on yield and its components of some faba bean varieties under newly reclaimed sandy soli condition. World J.Agric.Sci., 7(1): 68-72.

Basra, S.M.A.; M.N. Iftikhar and I. Afzal (2011). Potential of moringa (Moringa oleifera) leaf extract as priming agent for hybrid maize seeds. Int.J.Agric.Biol., 13: 1006-1010.

Beckingham, C. (2001). Snow peas and sugar snap peas. Agfact H8.1.35, second edition.

Ben-Shalom, N.; R. Ardi; R. Pinto; C. Aki and E. Fallik (2003). Controlling gray mould caused by Botrytis cinerea in cucumber plants by means of chitosan. Crop Protec., 22: 258-290.

Bozoglu, H.; E. Peksen; A. Peksen and A. Gulumser (2007). Determination of the yield performance and harvesting periods of fifteen pea (Pisum sativum L.) cultivars sown in Autumn and Spring. Pak.J.Bot., 39(6): 2017-2025.

Burt, J. (2008). Growing snow peas and sugar snaps in Western Australia. www.agric.wa.gov.au/content/hort/veg/cp peas/F05099.pdf.

Chen, W.G.; X. Liu and H.X. Chen (2009). Preparation of modified chitosan with quaternary ammonium salt. Textile Bioengineering and Informatics 
Symposium Proceedings, 1: 226-230.

Chibu, H. and H. Shibayama (2001). Effects of chitosan applications on the growth of several crops. In: Uragami, T.; K. Kurita and T. Fukamizo (Eds.), Chitin and chitosan in life science. Yamaguchi, pp: 235-239.

Culver, M.; T. Fanuel and C. A. Zvenhamo (2012). Effect of moringa extract on growth and yield of tomato. Greener Journal of Agricultural Sciences, 2 (5): 207-211.

De Alvarenga, E.S. (2011). Characterization and properties of chitosan, Biotechnology of Biopolymers, Prof. Magdy elnashar (Ed.), ISBN: 978953-307-179-4, InTech.

Dubois, M.; K.A. Gilles; J.K. Hamilton; P.A. Rebers and F. Smith (1956). Colorimetric method for determination of sugars and related substances. Anal.Chem., 28(3): 350-356.

El-Desuki, M. (2006). Effect of sowing date on productivity and exportable yield of some sugar pea (Pisum sativum var macrocarpon) cultivars in Shark El-owinat region. J.Agric.Sci.Mansoura Univ., 31(5): 3055-3065.

El hadrami, A.; L.R. Adam; I. El hadrami and F. Daayf (2010). Chitosan in plant protection. Mar.Drugs., 8: 968-987.

El Ghaouth, A.; J. Arul; R. Ponnampalam and M. Boulet (1991). Chitosan coating effect on storability and quality of fresh strawberries. J.Food Sci., 56(6): 1618-1620.

El-Miniawy, S.M.; M.E. Ragab; S.M. Youssef and A.A. Metwally (2013). Response of strawberry plants to foliar spraying of chitosan. Res.J.Agric. \& Biol.Sci., 9(6): 366-372.

El Nagar, M.M.; N.S.A. Shafshak; F.A.. Abo Sedera; A.A. Esmail and A.S. Kamel (2012). Effect of foliar spray by some natural stimulating compounds on growth, yield and chemical composition of peas (Pisum sativum L.). Annals of Agric.Sci., Moshtohor, 50(4): 463-472.

El Naim, A.M.; A. A. Jabereldar and E.A. Mohamed (2011). Effect of seed rate and cultivar on yield and yields components of cowpea (vigna unguiculata I.walp) in Kordofan of Sudan. International Journal of Current Research, 2(1): 142-147.

El-Tanahy, A.M.M.; A.R. Mahmoud; M.M. Abde-Mouty and A.H. Ali (2012). Effect of chitosan doses and nitrogen sources on the growth, yield and seed quality of cowpea. Aust.J.Basic \& Appl.Sci., 6(4): 115-121.

Epstein, E. (1994). The anomaly of silicon in plant biology. Proc. Natl. Acad. Sci. USA, 91: 11-17.

Epstein E. (1999). Silicon. Annu. Rev.Plant Physiol. Plant Mol. Biol., 50: 641664.

Farouk, S. and A.A. Ramadan (2012). Improving growth and yield of cowpea by foliar application of chitosan under water stress. Egyptian Journal of Biology, 14: 14-26.

Fuglie, L.J.(1999). The miracle tree: Moringa oleifera: natural nutrition for the tropics. Church World Service, Dakar, p 68.

Fuglie, L.J.(2000). The miracle tree: Moringa oleifera: natural nutrition for the tropics. In: The miracle tree: the multiple attributes of moringa. Wageningen, The Netherlands, p 172. 
Ghoname, A.A; M.A. El-Nemr; A.M.R. Abdel-Mawgoud and W.A. El-Tohamy (2010). Enhancement of sweet pepper crop growth and production by application of biological, organic and nutritional solutions. Res.J.Agric.\&Biol.Sci., 6(3): 349-355.

Gomez, K.A. and A.A. Gomez (1984). Statistical Procedures for the Agricultural Researches. John Wiley and Son, Inc.New York.

Greger, M.; T. Landberg; M. Vanculik and A. Lux (2011). Silicon influences nutrient status in plants. Proceedings of The $5^{\text {th }}$ International Conference on Silicon in Agriculture, Beijing, China, pp: 57-58.

Hussain, M.; M. Farooq; M.A. Shahzad; S.M.A. Basra and D. Lee (2013). Application of moringa alleopathy in crops sciences.In: Cheema et al (eds.), Allelopathy. Springer Berlin Heidelberg, pp: 469-483.

Jia, J.X.; D.L. Cai and Z.M. Liu (2011). New progress in silicon-improvement of quality of crops. Proceedings of The $5^{\text {th }}$ International Conference on Silicon in Agriculture, Beijing, China, pp 77.

Karimi, S.; H. Abbaspour; J.M. Sinaki and H. Makarian (2012). Effects of water deficit and chitosan spraying on osmotic adjustment and soluble protein of cultivars castor bean (Ricinus communis L.). J.Stress Physio.Bio., 8:160-169.

Khan, M.H.; K.LB. Singha and S.K. Panda (2002). Changes in antioxidant levels in Oryza sativa L. roots subjected to $\mathrm{NaCl}$ salinity stress. Acta Physiol.Plantarum, 24: 145-148.

Kim, H.J. (2005). Characterization of bioactive compounds in essential oils, fermented anchovy sauce, and edible plants, and induction of phytochemicals from edible plants using methyl jasmonate (MeJA) and chitosan. Ph.D.Thesis, Clemson University USA 178 pp.

Korndörfer G.H.; H.S. Pereira and A. Nolla (2004). Silicon analysis in soil, plant and fertilizers. Brazil, GPSi/ICIAG/UFU.

Mahmood, K.T; T. Mugal and I.U. Haq (2010). Moringa oleifera : a natural gift : a review. J.Pharm.Sci.Res., 2: 775-781.

Makkar, H.P.S. and K. Becker (1996). Nutritional value and antinutritional compounds of whole and ethanol extracted moringa oleifera leaves. Anim. Feed Sci.Technol., 63: 211-228.

Mali, M. and N.C. Aery (2009). Effect of silicon on growth, biochemical constituents and mineral nutrition of cowpea. Communication in Soil Science and Plant Analysis, 40: 1041-1052.

Matichenkov, V. and E. Bocharnikova (2004). Si in horticultural industry. Production Practices and Quality Assessment of Food Crops, 2: 217228.

Mondal, M.M.A.; M.A. Malek; A.B. Puteh; M.R. Ismail; M. Ashrafuzzaman and L. Naher (2012). Effect of foliar application of chitosan on growth and yield in okra. Australian Journal of Crop Science, 6(5): 918-921.

Mondal, M.M.A.; M.A. Malek; A.B. Puteh and M.R. Ismail (2013). Foliar application of chitosan on growth and yield attributes of mungbean (Vigna Radiata (L.) wilczek). Bangladesh J.Bot., 42(1): 179-183.

Muhamman, M.A.; B. M. Auwalu; A. A. Manga and J. M. Jibrin (2013). Effects of aqueous extract of moringa (Moringa oleifera Lam.) and nitrogen rates on some physiological attributes and yield of tomato. 
International Journal of Chemical, Environmental \& Biological Sciences, 1(1): 67-74

Munakamwe, Z.; G.D. Hill and B.A. McKenzie (2012). Yield response to pea (Pisum sativum L.) genotype, population and sowing date. The Open Agriculture Journal, 6: 47-56.

Photchanachai, S.; J. Singkaew and J. Thamthong (2006). Effect of chitosan seed treatment on colletotrichum $s p$. and seedling growth of chili cv. "Jinda". Acta Hort., 712:585-590.

Pilon, C.; R.P. Soratto and L.A. Moreno (2013). Effects of soil and foliar application of soluble silicon on mineral nutrition, gas exchange, and growth of potato plants. Crop Science, 53(4): 1605-1614.

Qiang, L.; P. Jian-wele; R. Xiang-min; X. Gul-xian and Z. Hong-mei (2007). Effect of carboxymethyl chitosan on nitrogen metabolism of rice. Plant Nutrition and Fertilizer Science, 13(4): 597.

Rasaei, A.; M. Ghobadi and M. Ghobadi (2012). Effect of supplemental irrigation and plant density on yield and yield components of peas (Pisum sativum L.) in Kermanshah Region. Am-Euras. J. Agric. \& Environ. Sci., 12 (3): 352-357.

Sajid M.; A. Rab; Noor-ul-Amin; Fazaliwahid; I. Jan; I. Ahmad; I. A. Khan and M. A. Khan (2012). Effect of herbicides and row spacing on the growth and yield of pea. Pak. J. Weed Sci. Res., 18(1): 1-13.

Shaukat, S.A.; Z. Ahmad, Y.A. Choudry and S.K. Shaukat (2012). Effect of different sowing dates and row spacing on the growth, seed yield and quality of off-season pea (Pisum sativum L. Cv. Climax) under temperate conditions of Rawalakot Azad Jammu and Kashmir. Scientific Journal of Agricultural, 1(5): 117-125.

Singh, R. and P.M. Singh (2011). Effect of sowing dates and varieties on yield and quality of garden pea seed. Vegetable Science, 38(2): 184187.

Snedecor, G.W. and W.G. Cochran (1968). Statistical Methods. Lowa State.Univ.Press, Ame., USA, $6^{\text {th }}$ Ed., P.393.

Snyder G.H.; V.V. Matichenkov and L.E. Datnoff. In: Barker A.V.; D.J. Pilbeam (2007), Eds. Silicon. Handbook of Plant Nutrition, CRC Press: Boca Raton FL, pp: 551-568.

Tewfik, S.S.A. (2014). Evaluation of growth, productivity and quality of some sugar pea cultivars under new reclaimed soil conditions. M.Sc.Thesis, Faculty of Agriculture, Ain Shams University, $86 \mathrm{pp}$.

Toresano-Sanchez, F.; M. Díaz-Perez; F. Dianez-Martinez and F. CamachoFerre (2010). Effect of the application of monosilicic acid fertilizer on yield and quality of greenhouse triploid watermelon. Acta Hort. (ISHS) 927:373-377.

Toresano-Sanchez, F.; A. Vaverde-Garcia and F. Camacho-Ferre (2012). Effect of the application of silicon hydroxide on yield and quality of cherry tomato. Journal of Plant Nutrition, 35: 567-590.

Turk, M.; S. Albayrak and O. Yuksel (2011). Effect of seeding rate on the forage yields and quality in pea cultivars of different leaf types. Turkish Journal of Field Crops, 16(2): 137-141. 
Vasanthi N.; M. L. Saleena and S. A. Raj (2012). Silicon in Day Today Life. World Appl. Sci. J., 17(11): 1425-1440.

Wojdyla, A.T. (2001). Chitosan in the control of rose disease-6 year trials. Bull.Polish Acad.Sci.Bio.Sci., 49: 233-252.

Xie, W.; P. Xu and Q. Liu (2001). Antioxidant activity of water-soluble chitosan derivatives. Bioorg.Med.Chem.Lett, 11:1699-1701.

Yasmeen, A.; S. Maqsood, A. Basra, M. M. Javaid; Hafeez-ur-rehman; Abdul wahid and N. Hussain (2012). Effect of exogenous application of natural and synthetic growth enhancers on quantitative and qualitative attributes of tomato (Lycopersicum esculentum). $12^{\text {th }}$ National and $3^{\text {rd }}$ International Conference of Botany, Quaid-e-Azam University, Islamabad, Pakistan.

Yucel, D.O. (2013). Impact of plant density on yield and yield components of pea (Pisum sativum ssp. Sativum L.) cultivars. ARPN Journal of Agricultural and Biological Science, 8(2): 169-174.

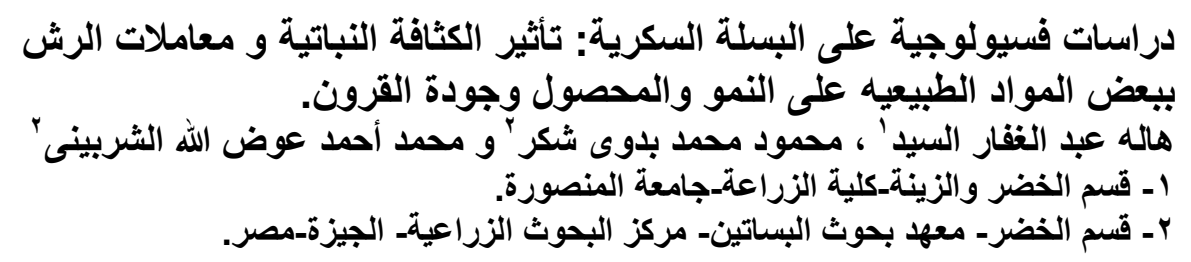

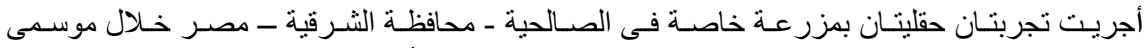

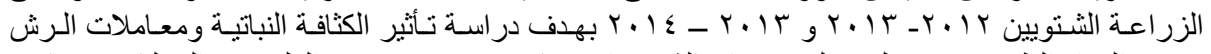

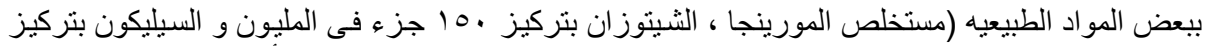

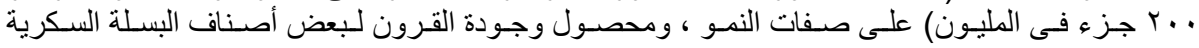

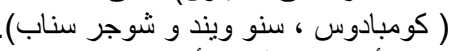

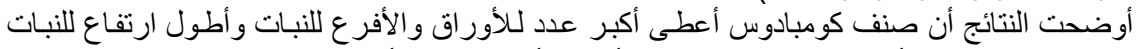

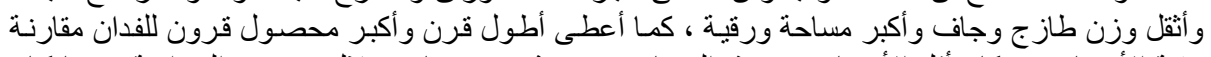

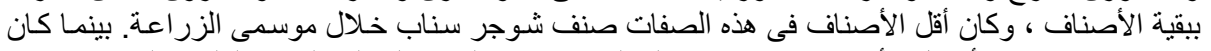

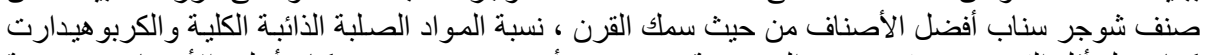

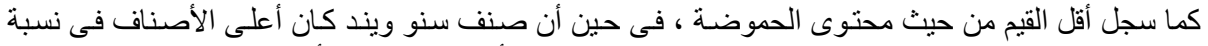

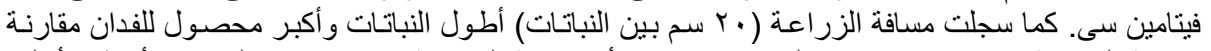

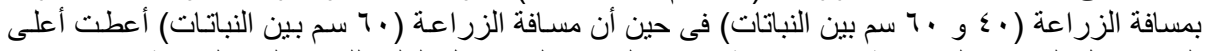

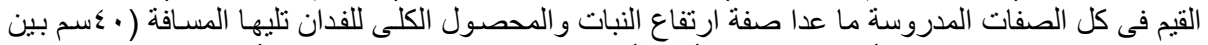

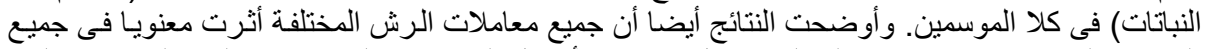

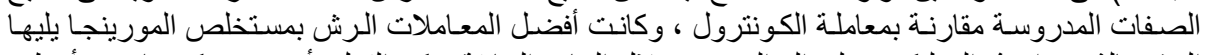

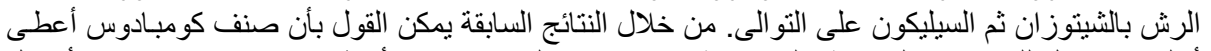

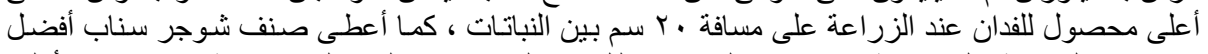

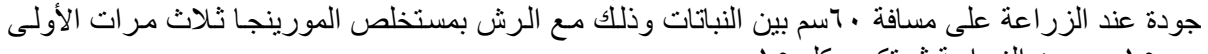

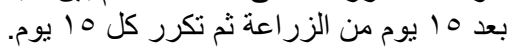


J. Plant Production, Mansoura Univ., Vol. 5 (7): 1259-1281, 2014

Table (2): Effect of cultivars, plant density and foliar applications on vegetative growth parameters of sugar pea in the two seasons of 2012/2013 and 2013/2014.

\begin{tabular}{|c|c|c|c|c|c|c|c|c|c|c|c|c|c|}
\hline \multirow{2}{*}{\multicolumn{2}{|c|}{ Treatments }} & \multicolumn{2}{|c|}{ Plant height (cm) } & \multicolumn{2}{|c|}{$\begin{array}{c}\text { No of branches/ } \\
\text { plant }\end{array}$} & \multicolumn{2}{|c|}{$\begin{array}{c}\text { No of } \\
\text { leaves/plant }\end{array}$} & \multicolumn{2}{|c|}{ Leaf area/plant $\left(\mathrm{cm}^{2}\right)$} & \multicolumn{2}{|c|}{$\begin{array}{c}\text { Fresh weight/plant } \\
(\text { gm) }\end{array}$} & \multicolumn{2}{|c|}{$\begin{array}{c}\text { Dry weight/plant } \\
\text { (gm) }\end{array}$} \\
\hline & & S1 & S2 & S1 & S2 & S1 & S2 & S1 & S2 & S1 & S2 & S1 & S2 \\
\hline \multirow{3}{*}{ Cvs. } & Compados & 58.19 & 75.66 & 4.88 & 3.77 & 45.83 & 38.77 & 3854.27 & 3579.31 & 220.62 & 182.68 & 31.96 & 29.65 \\
\hline & Sugar Snap & 52.19 & 54.02 & 3.97 & 3.11 & 38.25 & 33.38 & 2167.36 & 2054.08 & 155.31 & 113.44 & 23.26 & 22.41 \\
\hline & Snow Wind & 54.05 & 61.25 & 4.36 & 3.27 & 38.83 & 34.94 & 2488.91 & 2287.35 & 162.19 & 131.37 & 23.76 & 23.32 \\
\hline \multicolumn{2}{|c|}{ L.S.D at $5 \%$} & 2.269 & 0.965 & 0.166 & 0.353 & 1.379 & 1.727 & 25.493 & 13.568 & 4.019 & 4.196 & 0.868 & 1.864 \\
\hline \multirow{3}{*}{ Density } & $20 \mathrm{~cm}$ & 57.94 & 65.80 & 3.94 & 3.05 & 38.27 & 34.02 & 2574.52 & 2211.72 & 170.52 & 138.25 & 23.66 & 22.55 \\
\hline & $40 \mathrm{~cm}$ & 54.27 & 63.36 & 4.41 & 3.41 & 40.80 & 35.58 & 2947.57 & 2766.84 & 181.02 & 142.91 & 25.99 & 25.57 \\
\hline & $60 \mathrm{~cm}$ & 52.22 & 61.77 & 4.86 & 3.69 & 43.83 & 37.50 & 2988.46 & 2942.19 & 186.58 & 146.33 & 29.32 & 27.25 \\
\hline \multicolumn{2}{|c|}{ L.S.D at $5 \%$} & 1.883 & 1.566 & 0.392 & 0.218 & 1.353 & 1.283 & 14.825 & 23.682 & 2.880 & 2.599 & 1.029 & 0.962 \\
\hline \multirow{4}{*}{ Foliar } & MLE & 58.48 & 66.96 & 4.92 & 4.03 & 46.55 & 38.88 & 3187.59 & 2938.68 & 196.79 & 147.45 & 29.91 & 28.00 \\
\hline & Chitosan & 56.07 & 63.74 & 4.51 & 3.40 & 41.33 & 36.51 & 2981.22 & 2774.46 & 184.70 & 144.22 & 27.44 & 26.06 \\
\hline & Silicon & 54.70 & 62.74 & 4.29 & 3.18 & 40.55 & 34.92 & 2892.90 & 2679.71 & 183.27 & 145.33 & 25.70 & 24.89 \\
\hline & Control & 50.00 & 61.14 & 3.88 & 2.92 & 35.44 & 32.48 & 2285.68 & 2168.15 & 152.74 & 132.99 & 22.25 & 21.55 \\
\hline \multicolumn{2}{|c|}{ L.S.D at $5 \%$} & 1.829 & 1.439 & 0.319 & 0.285 & 1.525 & 1.086 & 17.579 & 15.322 & 2.874 & 1.867 & 0.910 & 0.839 \\
\hline
\end{tabular}

S1: 2012/2013 season, S2: 2013/2014 season and MLE: moringa leaf extract. 
Table (4): Effect of the triple interaction among cultivars, plant density and foliar applications on vegetative growth parameters of sugar pea in the two seasons of 2012/2013 and 2013/2014.

\begin{tabular}{|c|c|c|c|c|c|c|c|c|c|c|c|c|c|c|}
\hline \multirow{2}{*}{\multicolumn{3}{|c|}{ Treatments }} & \multicolumn{2}{|c|}{ Plant height (cm) } & \multicolumn{2}{|c|}{$\begin{array}{l}\text { No of branches/ } \\
\text { Plant }\end{array}$} & \multicolumn{2}{|c|}{$\begin{array}{c}\text { No of } \\
\text { leaves/plant }\end{array}$} & \multicolumn{2}{|c|}{ Leaf area/plant $\left(\mathrm{cm}^{2}\right)$} & \multicolumn{2}{|c|}{$\begin{array}{c}\text { Fresh weight } \\
(\text { gm })\end{array}$} & \multicolumn{2}{|c|}{$\begin{array}{c}\text { Dry weight/plant } \\
(\mathrm{gm})\end{array}$} \\
\hline & & & S1 & S2 & S1 & S2 & S1 & S2 & S1 & S2 & & & & \\
\hline \multirow{12}{*}{$\begin{array}{l}\frac{0}{0} \\
\frac{0}{\pi} \\
\frac{0}{g} \\
\delta \\
0\end{array}$} & & MLE & 71.00 & 85.33 & 5.00 & 4.33 & 52.00 & 39.66 & 4488.29 & 3722.53 & 231.49 & 183.84 & 34.19 & 31.36 \\
\hline & & Chitosan & 65.00 & 77.00 & 4.33 & 3.33 & 38.66 & 36.66 & 3080.22 & 2883.56 & 212.35 & 173.19 & 30.78 & 24.71 \\
\hline & $20 \mathrm{~cm}$ & Silicon & 60.66 & 75.66 & 4.33 & 3.33 & 43.33 & 34.66 & 3164.63 & 2845.17 & 220.63 & 182.40 & 25.71 & 24.45 \\
\hline & & Control & 54.33 & 72.66 & 3.66 & 3.00 & 35.66 & 34.00 & 2898.26 & 2719.29 & 192.51 & 170.51 & 23.25 & 22.34 \\
\hline & & MLE & 59.66 & 80.00 & 5.66 & 4.66 & 53.00 & 43.33 & 4451.11 & 4187.05 & 238.03 & 187.01 & 35.43 & 33.76 \\
\hline & & Chitosan & 58.00 & 77.33 & 5.00 & 3.66 & 47.00 & 37.33 & 4334.09 & 4164.09 & 219.62 & 181.20 & 32.66 & 31.89 \\
\hline & $40 \mathrm{~cm}$ & Silicon & 56.66 & 73.33 & 5.00 & 3.66 & 46.33 & 36.66 & 3920.69 & 3904.02 & 224.47 & 185.94 & 31.84 & 31.32 \\
\hline & & Control & 51.00 & & 5.00 & 3.33 & 36.66 & 36.00 & 2879.83 & & 198.05 & 177.03 & 24.34 & 25.28 \\
\hline & & MLE & 57.00 & 78.66 & 6.00 & 5.00 & 57.66 & 47.33 & 4503.94 & 4292.96 & 240.08 & 190.79 & 40.15 & 35.79 \\
\hline & & Chitosan & 58.33 & 75.33 & 5.33 & 4.00 & 50.00 & 42.66 & 4464.19 & & 239.56 & 188.86 & & 34.22 \\
\hline & $60 \mathrm{~cm}$ & Silico & & 72.6 & 5.00 & 3.66 & 47.00 & 39.3 & 4361.83 & & 228.62 & 191.78 & 37.58 & $\frac{04.2 L}{33.92}$ \\
\hline & & & & & 4.33 & 3.33 & 42.6 & 37.6 & & 3097.86 & 202.04 & 179.63 & 28.06 & 26.82 \\
\hline \multirow{12}{*}{ 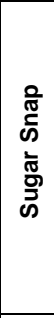 } & & MLE & 57.66 & 56.66 & 4.00 & 3.33 & 38.33 & 32.66 & 1887.11 & 1832.78 & 153.65 & 118.28 & 25.72 & 22.01 \\
\hline & & Chitosan & 55.00 & 55.66 & 3.66 & 3.00 & 34.66 & 33.66 & 2058.88 & 1922.67 & 133.81 & 115.69 & 21.32 & 22.47 \\
\hline & $20 \mathrm{~cm}$ & Silicon & 53.33 & 54.33 & 4.00 & 2.66 & 36.33 & 31.66 & 1845.74 & 1764.74 & 149.30 & 114.74 & 19.64 & 19.16 \\
\hline & & Control & 50.00 & 53.66 & 3.00 & 2.33 & 29.66 & 30.00 & 1531.25 & 1454.58 & 114.38 & 86.35 & 18.53 & 18.20 \\
\hline & & MLE & 55.33 & 56.33 & 4.33 & 3.66 & 42.33 & 35.66 & & 2196.58 & 173.18 & 119.12 & 27.24 & 25.77 \\
\hline & & Chitosan & 53.00 & 54.66 & 4.00 & 3.33 & 38.00 & 34.33 & & 196 & 173.22 & 118.00 & 22.68 & 23.41 \\
\hline & $40 \mathrm{~cm}$ & & 52.33 & 53.33 & 4.00 & 3.00 & 36 & 33.33 & 2168.94 & 2133.28 & 164.35 & 117.01 & & 21.27 \\
\hline & & Control & 49.33 & 52.33 & 3.66 & 2.66 & 35. & 31.00 & 1914.77 & 1912.41 & 135.05 & 102.25 & 20.66 & 19.16 \\
\hline & & MLE & & 54.6 & 4.33 & 4.00 & & & & 253 & & 125.44 & 28.50 & 28.37 \\
\hline & & $\overline{\mathrm{c}}$ & & & 4.33 & 3.33 & & & & & & & 25.91 & 25.55 \\
\hline & $60 \mathrm{~cm}$ & Silicor & 50 & 52. & 4.33 & 3.00 & 40 & 34.33 & & 2456.72 & 167.66 & 118.09 & 25.33 & 22.36 \\
\hline & & Contro & 46 & 51. & 4.00 & 3.00 & 35 & 32 & & 197 & 139.35 & 104.17 & 21.46 & 21.18 \\
\hline \multirow{13}{*}{ 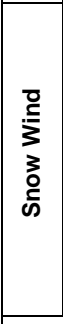 } & & ML & & & & 3.33 & & 36 & & & & 131.10 & 22.35 & 21.90 \\
\hline & & Chitosan & 57.33 & & 4.00 & 3.00 & 39.66 & 35.66 & & 195 & 165.99 & 130 & 22.14 & 22.49 \\
\hline & $20 \mathrm{~cm}$ & Silico & & 66.00 & 3.33 & 2.66 & 37.66 & 34. & & 203 & 159.65 & 130 & 21.11 & 22.02 \\
\hline & & Contrc & 51.33 & 62.66 & 3.33 & 2.33 & 32.33 & 29 . & & 1477 & 129.19 & 122 & 19.23 & 19.56 \\
\hline & & MLE & & 61.66 & 4.66 & 3.66 & 41.66 & 38.00 & 3143.47 & 2840.71 & 184.28 & 135 & 25.70 & 25.39 \\
\hline & & Chitos & 56.00 & 60.00 & 4.33 & 3.33 & 40.33 & 36.33 & 3181.27 & 2640.95 & 168.24 & 133.36 & 25.38 & 24.79 \\
\hline & $40 \mathrm{~cm}$ & Silico & 54.00 & 58.66 & 3.66 & 3.00 & 38.00 & 34. & 3002.86 & 2393.39 & 162.80 & 132.73 & 22.50 & 24.77 \\
\hline & & Contrc & & 62.00 & & 3.00 & & 30.66 & & 196 & 131.00 & 126 & 21.31 & 20.12 \\
\hline & & & & & 5.66 & 4.33 & 44 & 39.66 & & & 187.33 & 136 & 29.90 & 27.66 \\
\hline & $60 \mathrm{~cm}$ & & & & & 3.66 & 41 & 37. & & 27 & 169.45 & & 26.55 & 25.02 \\
\hline & $60 \mathrm{~cm}$ & Sili & & 58. & 5. & 3.66 & 39.00 & 36.00 & & 256 & 171.96 & 135.18 & 25.49 & 24.79 \\
\hline & & Control & 48.33 & 55.66 & 4.33 & 3.33 & 36.66 & 31.66 & 20 & 2014.38 & 133.09 & 128.17 & 23.43 & 21.33 \\
\hline & $-S$ & at $5 \%$ & NS & NS & NS & NS & NS & NS & 52.737 & 45.967 & 8.624 & NS & NS & NS \\
\hline
\end{tabular}

S1: 2012/2013 season, S2: 2013/2014 season, MLE: moringa leaf extract and NS: not significant at 0.05 level of significance. 
